Document downloaded from:

http://hdl.handle.net/10251/157308

This paper must be cited as:

Guardiola Villora, AP.; Basset-Salom, L. (2020). Earthquake risk scenarios of the Ciutat Vella District in Valencia, Spain. Bulletin of Earthquake Engineering. 18(4):1245-1284. https://doi.org/10.1007/s10518-019-00745-7

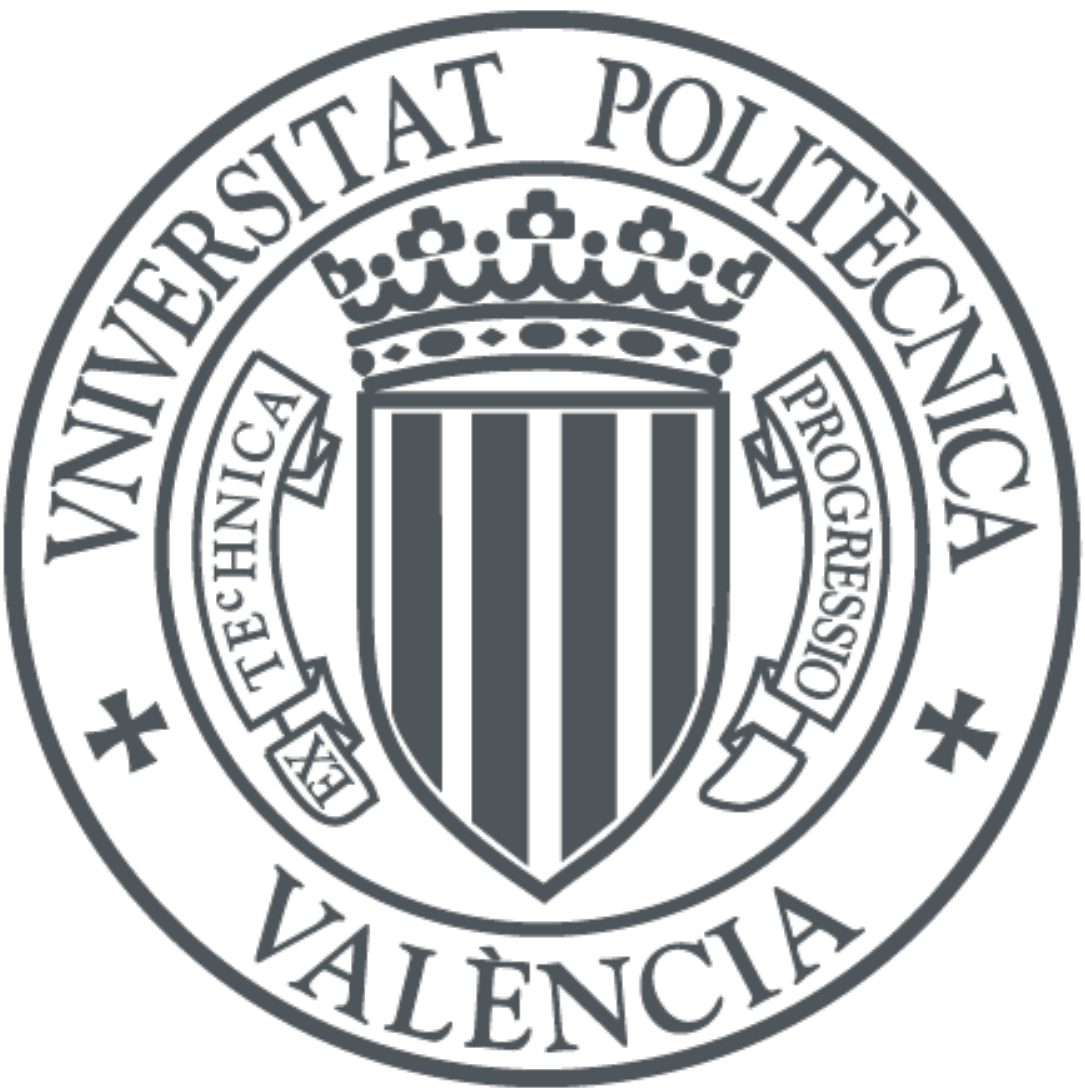

The final publication is available at

https://doi.org/10.1007/s10518-019-00745-7

Copyright Springer-Verlag

Additional Information 


\title{
Earthquake risk scenarios of the Ciutat Vella District in Valencia, Spain
}

\author{
Arianna Guardiola-Víllora, Luisa Basset-Salom
}

\begin{abstract}
According to the United Nations Office for Disaster Risk Reduction cities must take measures to anticipate disasters and mitigate their impact, protecting homes and cultural heritage, minimizing losses due to earthquakes and other threats. After the recent earthquakes in historical city centres, the evaluation of the seismic risk, even in regions of low or moderate seismicity, is imperative, being damage assessment and loss estimation essential for its reduction.

In this paper the seismic risk analysis of the residential buildings in the Ciutat Vella District in Valencia, with great historical and architectural value, is presented.

The vulnerability of Ciutat Vella has been assessed with the Vulnerability Index Method establishing the seismic quality of the residential buildings according to their structural typology, conservation status, age and geometry; identifying the most vulnerable buildings. Damage probability matrices have been obtained for the deterministic and probabilistic earthquake scenarios, estimating for each of them, the seismic risk in terms of direct social and economic losses, mapping the results using a GIS system tool.

Results confirm that the vulnerability of the building stock in Ciutat Vella is high being the seismic risk significant. In the event of an earthquake, many residential buildings included in the Catalogue of Listed Buildings of the Special Protection Plan of Ciutat Vella will be damaged.

A detailed analysis of the most vulnerable buildings will provide criteria for intervention to enhance their structural seismic response, safeguarding the architectural heritage and contributing to the reduction of human and material losses.
\end{abstract}

Keywords:

Vulnerability index method, damage assessment, seismic risk scenarios, loss estimation, urban areas, Ciutat Vella.

\footnotetext{
Ariana Guardiola-Víllora (Corresponding author)

Departamento de Mecánica de Medios Continuos y Teoría de Estructuras, Universitat Politècnica de València, cno de Vera s/n, 46022 Valencia, Spain aguardio@mes.upv.es

Luisa Basset-Salom

Departamento de Mecánica de Medios Continuos y Teoría de Estructuras, Universitat Politècnica de València, cno de Vera s/n, 46022 Valencia, Spain

LBASSET@mes.upv.es
} 


\section{INTRODUCTION}

The aim of all seismic vulnerability assessment is to predict the expected damage in existing buildings in case of occurrence of a given earthquake as well as being a basic element in the planning of the earthquake mitigation effects. The occurrence of recent earthquakes in historical city centres (L'Aquila 2009, Lorca 2011, Emilia Romagna 2012, Amatrice 2016) confirms the need for this assessment including the establishment of deterministic and probabilistic scenarios based on the seismicity of the area, the seismic vulnerability analysis of the existing buildings as detailed as possible, and the estimation of the expected social and economic losses.

Like many cities located in areas of low or moderate seismic hazard, seismic risk in Valencia is high due to the significant vulnerability of the buildings, as shown in a previous study of residential buildings in L'Eixample district of Valencia (Guardiola-Víllora and Basset-Salom 2015). Despite of the current technical knowledge enabling design and proper construction to withstand seismic actions, many buildings don't meet the necessary requirements, especially those which were built before the first Spanish Seismic Code. In fact, the Special Plan against Earthquake Risk in Valencia Region (Decree 44/2011 April 29 ${ }^{\text {th }}$ ), which includes a large-scale study of the whole territory, recommends the development of a specific seismic plan the city of Valencia amongst many other municipalities in the Valencian Community.

This research focus on the residential buildings of the district of Ciutat Vella, the ancient city laying inside the walls demolished in 1865 , with great historical and architectural value. The majority of the buildings correspond to unreinforced masonry typologies, except those built after 1950 which are mainly reinforced concrete buildings. Regardless of the typology, all the buildings, except the most recent ones, were calculated and designed considering only vertical actions neglecting, in addition, other factors which influence their vulnerability, such as, for instance, geometric or stiffness irregularities. Moreover, given that interventions of different types are currently taking place in the district (renovation, rehabilitation, retrofitting, etc.), obtaining the expected degree of damage can be very useful to identify the most vulnerable buildings and improve their seismic performance.

There are different approaches to assess the seismic vulnerability of buildings (Calvi et al. 2006, Barbat et al. 2010, D'Ayala 2013, Novelli 2017) namely empirical methods based on post-earthquake damage observation and construction data such as the Damage Probability Matrix, DPM (Whitman et al. 1973, Dolce et al. 2003) or the Vulnerability Index Methods, VIM (Benedetti and Petrini 1984, Benedetti et al. 1988, Giovinazzi and Lagomarsino 2002, Milutinovich and Trendafiloski 2003); analytical methods based on numerical models (Bernardini et al. 1990, D’Ayala and Speranza 2002, Barbat et al. 2008, Irizarry et al. 2011, Lamego et al. 2017) and hybrid methods (Barbat et al. 1996, Kappos et al. 1998, Kappos et al. 2006, Maio et al 2015, Ferreira et al. 2017).

The choice of the most appropriate method of vulnerability and risk assessment depends mainly on the scale and objectives of the study, the available data or resources for data collection and the type of the required results (Tyagunov et al. 2004, Guéguen et al 2007, Vicente et al. 2011, Chever 2012, Athmani et al. 2015, Novelli 2017).

The vulnerability of the Ciutat Vella District has been assessed with the Vulnerability Index Method, level 1 (Milutinovic and Trendafiloski 2003), developed under the framework of the European research project Risk-UE (Mouroux et al. 2004) which assigns, to each structural typology, the most likely vulnerability index $\mathrm{VI}^{*}$, the endpoints of the plausible interval [VI-; VI+] together with the lower and upper bounds of the possible values [VI ${ }^{\min } ; \mathrm{VI}^{\max }$ ] (Giovinazzi y Lagomarsino, 2004).

Risk-UE level 1 Vulnerability Index Method (VIM) is suitable to estimate the seismic vulnerability of buildings at urban areas where hazard microzonation maps or adequate estimates on the seismic intensity and building stock information (implemented from a building cadastral database, onsite visual screening or by taking representative buildings of the total building stock) are available. Examples of the use of this method in studies carried out in Spain include Barcelona (Roca et al. 2006, Lantada 2007, Lantada et al. 2010, Lantada et al 2018), Vélez-Málaga (Feriche et al. 2009), Gerona (Irizarry et al. 2012), Granada (Feriche 2012), Valencia (Guardiola-Víllora and Basset-Salom 2015) and Lorca (Feriche et al. 2012, Martínez-Cuevas and Gaspar-Escribano 2016, Rodenas et al 2018) among others.

With this method, the seismic quality of the buildings is defined by means of a vulnerability index derived from the structural typologies and subsequently modified according to the specific characteristics of the building which can contribute positively or negatively to its seismic performance. Damage probability matrices are then obtained for the deterministic and probabilistic earthquake scenarios previously defined. 
The basic geometrical information (height, age and dimensions) of the residential buildings has been obtained from the cadastral database. Specific information required for the vulnerability assessment such as the vertical and horizontal structural system has been retrieved from the Municipal Historic Archive of Valencia, the Special Protection Plans of Ciutat Vella, the Archive of the Architectural Information Centre of the School of Architecture of Valencia, among others, being checked, completed and improved through a comprehensive field survey of the whole district stock, obtaining additional information (state of preservation, retrofitting interventions, aseismic devices, type of floors, etc.) and identifying new plots, new buildings and some inconsistencies mainly regarding the structural system and the official age of the buildings (i.e. the cadastral age corresponds to the year of a minor change in the building instead of to the age of construction). A database of the residential buildings has been created for this study within a GIS environment, combining geo-referenced graphical data with the building stock characteristics.

Finally, for each earthquake scenario, the seismic risk in terms of direct social losses (potential number of casualties and homeless people) and economic losses (uninhabitable buildings and repair/replacement costs) has been estimated, taking into account the building typology, the occupancy rate, the probability of occurrence of each state of damage and the cost of repair/replacement. Results have been mapped using the GIS system tool.

\section{DESCRIPTION OF THE CIUTAT VELLA DISTRICT}

Valencia's historic centre, known as "Ciutat Vella", is one of the biggest in Europe. With an area of 169.10 ha and a registered population of 27259 inhabitants, Ciutat Vella is part of the Artistic Historical Site of Valencia Historic Centre, declared in 1993 Asset of Cultural Interest. Its boundaries are shown in figure 1a, being delimited in the North and East by the Turia river, (nowadays the $7 \mathrm{~km}$ Turia's garden in green) and in the West and South by the old route of the $16^{\text {th }}$ century defensive walls (now a ring road). Since the roman establishment in 138 B.C. until the demolishment of the defensive walls in 1865, the city experienced a series of wall-delimited expansions: the Arabian, ca1050, and the Medieval, ca1350; increasing the area from 46 to 169.10 hectares of late medieval urban fabric. (Ortiz Herrada 2002).

The Roman settlement, the Arabic and the Medieval walls are depicted in the map of the urban expansion project of the old city centre (Llopis et al. 2004), dated 1858. This map (figure 1b) shows that the shape of Ciutat Vella has remained nearly unchanged despite the continuous urban growth from the Roman era to the present
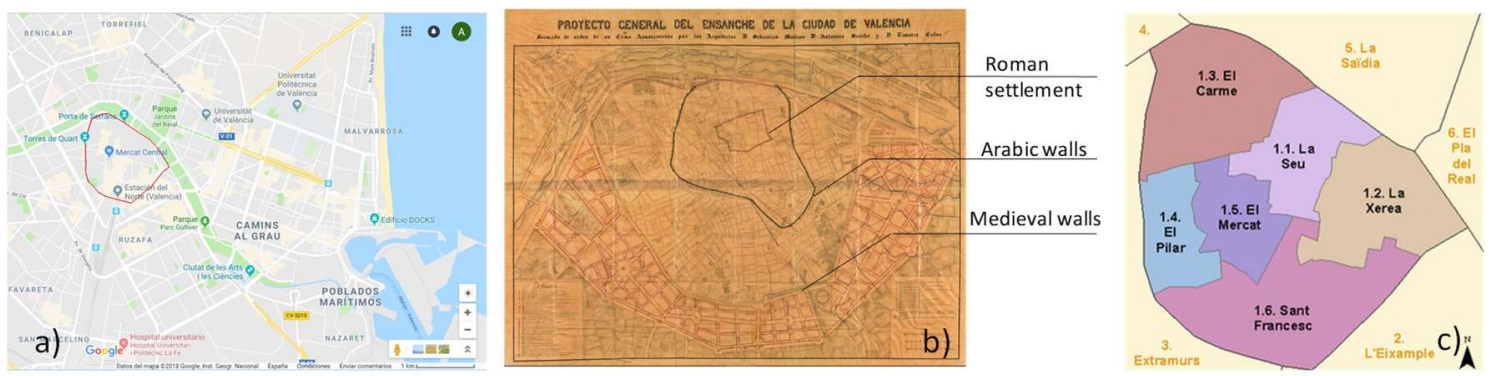

Fig. 1 a) Ciutat Vella boundaries (google maps 2018). b) Roman settlement, Arabic and Medieval walls, map of the urban expansion project of the old city centre, 1858 (Llopis et al. 2004); c) Ciutat Vella neighbourhoods (Ayuntamiento de Valencia 2017)

Ciutat Vella is divided into 6 neighbourhoods as shown in figure 1c, (Ayuntamiento de Valencia 2017): La Seu, La Xerea, El Carme, El Pilar, El Mercat, and Sant Francesc, being the characteristics of the buildings and the population different for each one.

La Seu $\left(0.221 \mathrm{~km}^{2}, 3097\right.$ inhabitants), the oldest neighbourhood, occupies the area of Valentia Edetanorum, the ancient Roman settlement. It is the political and religious centre known by its rich artistic heritage including, among others, medieval palaces transformed into residential buildings.

La Xerea, $\left(0.312 \mathrm{~km}^{2}, 3889\right.$ inhabitants) was the Arabic city centre's outskirts until the second part of the $14^{\text {th }}$ century, being included in the old town with the construction of the Arabic wall. In this quarter, old and ruined residential buildings coexist with new and well-preserved constructions.

El Carme $\left(0.384 \mathrm{~km}^{2}, 6370\right.$ inhabitants), one of the largest neighbourhoods and the most densely populated, is located between the Arabic and the Medieval walls. It has suffered significative alterations in the last thousand years, hosting Muslim refugees, craftsmen, medieval aristocracy, nuns and industrial revolution workers. Nowadays residential buildings from the 1700 s coexist with new ones. 
El Pilar (0.162 km², 4709 inhabitants), formerly known as "Velluters", grouped silk artisans (velluters in valencian language) until the $19^{\text {th }}$ century silk crisis, becoming thereafter a degraded residential area. Nowadays, the building stock consists mostly of social housing, including both buildings from the $19^{\text {th }}$ century and others built after the Spanish Civil War and the $60 \mathrm{~s}$.

El Mercat $\left(0.173 \mathrm{~km}^{2}, 3584\right.$ inhabitants) was, as la Xerea, the Arabic city centre's outskirts until the construction of the Medieval walls in the $14^{\text {th }}$ century. Some emblematic buildings in El Mercat are part of the rich artistic heritage of Valencia, namely the gothic Silk Exchange Centre (declared a World Heritage Site by UNESCO) or the modernist Central Market (declared Heritage of Cultural interest by the Spanish Ministry of Culture). More than $40 \%$ of the residential buildings were built in the $19^{\text {th }}$ century, being of better quality than the ones in el Pilar.

Sant Francesc $(0.439 \mathrm{~km} 2,5600$ inhabitants), was developed within the area of Saint Francis Monastery demolished at the end of the $19^{\text {th }}$ century. It is a financial and service district with wide avenues and squares comprising the tallest residential buildings, the City Hall, the Post Office, Hotels, Museums, etc.

Figure 2 includes a residential building from each neighbourhood, to show the value of the historic district of Ciutat Vella and the diversity of architectural styles and periods.
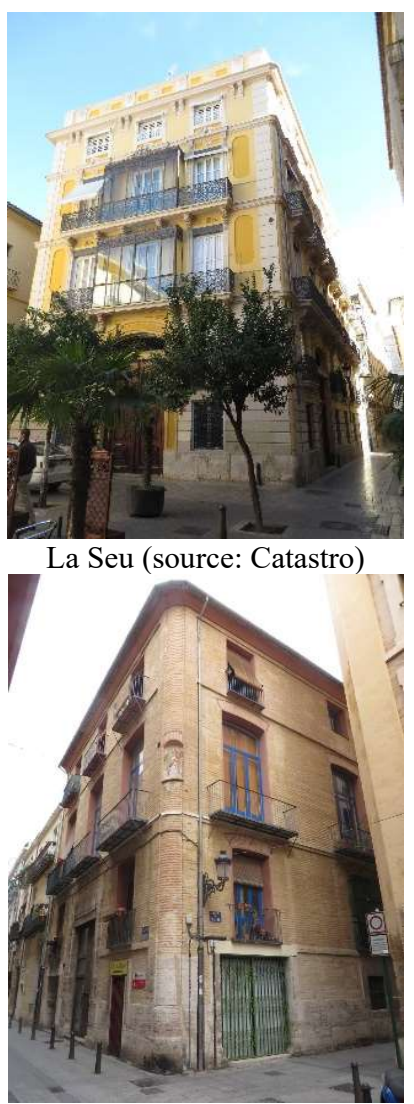

El Pilar (source: Catastro)
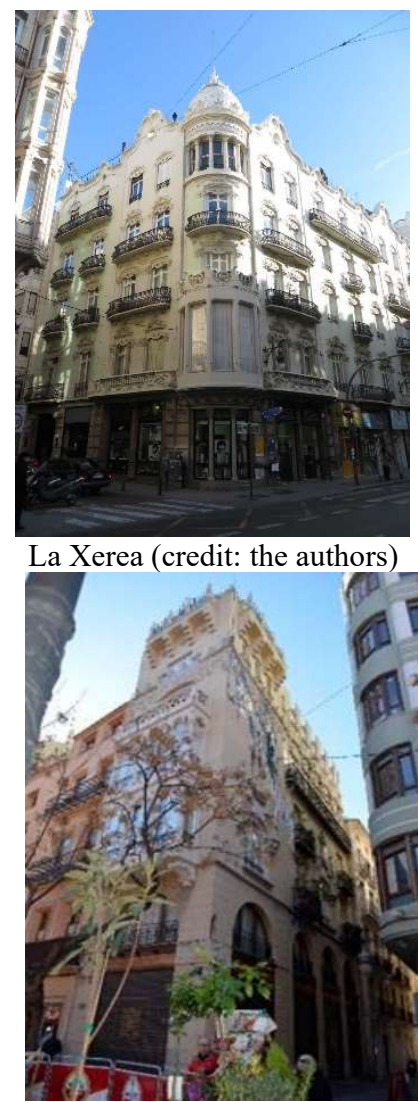

El Mercat (credit: the authors)

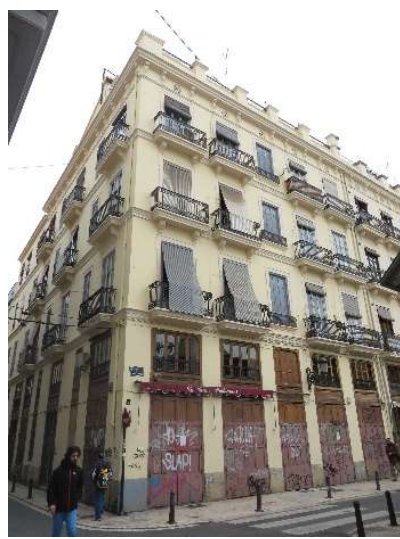

EL Carme (source: Catastro)

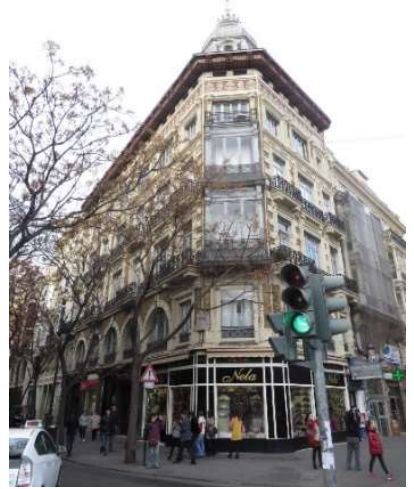

San Francesc (source: Catastro)

Fig. 2 Residential buildings in Ciutat Vella

In the seventies Valencia's historic centre was threatened by an increase of the population followed by the need of new housing. To preserve the ancient buildings, from 1979 to 1984 the Special Protection Plans named PEPs ("Planes Especiales de Protección ") were developed for each neighbourhood. They were replaced in 1992 by the PEPRIs ("Plan Especial de Reforma Interior") a set of new Special Protection Plans for Internal Regeneration oriented not only to protect the ancient buildings but to improve the building stock and urbanism of the city centre. New plans focusing in the analysis of the surroundings of special sights named "Planes de Entornos BIC" were developed at the end of the $20^{\text {th }}$ century and the beginning of the $21^{\text {st }}$ century. Being the different set of protection plans sometimes contradictory, the urban authorities decided in 2015 to carry out a deep revision, considering new protection, rehabilitation and reconstruction criteria according to leading European theories. A new protection plan, PEP Ciutat Vella, will be approved shortly. The database developed for this study has taken the information of the protection grades and the structural typologies from the PEP catalogue.

According to the cadastral database, Ciutat Vella has 3186 plots, from which 436 are non-residential corresponding to religious, museums, and historical buildings dating from the $13^{\text {th }}, 14^{\text {th }}, 15^{\text {th }}, 16^{\text {th }}$, and $17^{\text {th }}$ centuries, as well as administrative, financial, commercial, hotels, and cultural buildings from the $19^{\text {th }}, 20^{\text {th }}$ and $21^{\text {st }}$ centuries. The remaining 2750 plots correspond to residential buildings built from 1700 to 2017 , 
except 289 being empty plots. These residential buildings are distributed among the six neighbourhoods as follows: La Seu, $14.5 \%$ (13\% of the built area), La Xerea, $14.7 \%$ (18.4\% of the built area), El Carmen, $22.2 \%$ (22.7\% of the built area), El Pilar, $13.1 \%$ (9.5\% of the built area); El Mercat, $20.1 \%$ (10.3\% of the built area) and Sant Francesc, $15.4 \%$ (26.1\% of the Built area). The majority of the residential empty plots or ruined buildings (see figure 3 ) are located in el Carmen (40\%), despite the urban regeneration policies held by the local government in the 90's in Ciutat Vella. Figure 4 shows the distribution of area, residential buildings and empty plots/ruined buildings (in percentage) across Ciutat Vella's neighbourhoods.

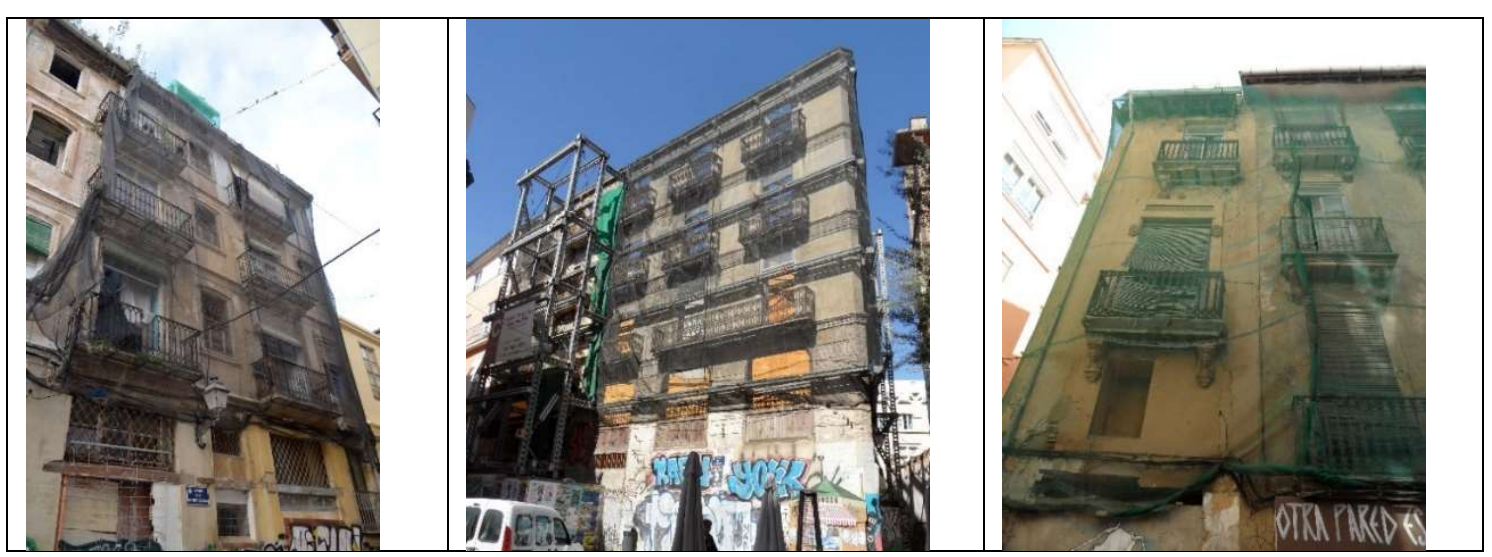

Fig. 3 Ruined buildings in Ciutat Vella (credit: the authors)

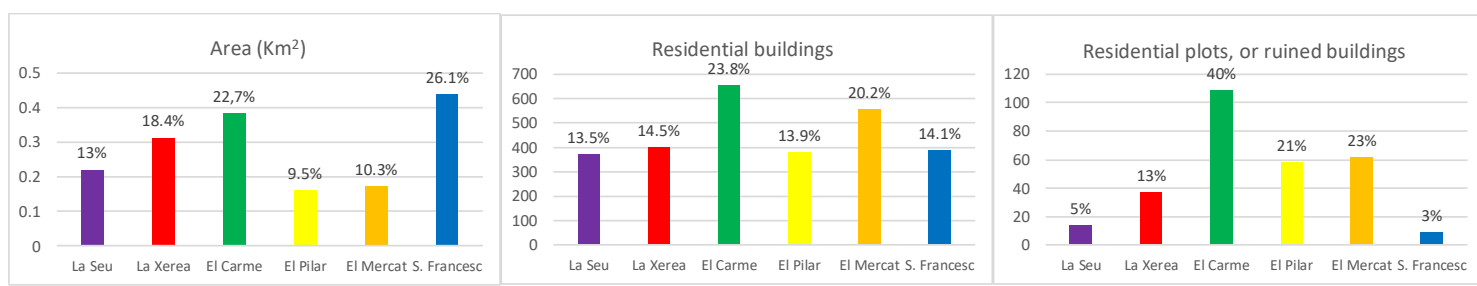

Fig. 4 Area, residential buildings and empty plots/ruined buildings in each neighbourhood

The oldest residential buildings standing up were built in 1700 in El Carme ( 8 buildings) and El Mercat ( 1 building). In total 43 residential buildings were built in the $18^{\text {th }}$ century, being El Carme and El Mercat the neighbourhoods (Figure 5) with the highest percentage of residential buildings of this period $(3.1 \%$ and $3 \%$ respectively). More than $1 / 3$ of the residential buildings of La Seu, El Carmen and El Mercat date from the $19^{\text {th }}$ century, while about $50 \%$ in La Xerea and Sant Francesc were built in the beginning of the $20^{\text {th }}$ century. It is important to stress that the number of new buildings has decreased since 1975 in Sant Francesc and La Xerea, being steady in El Carmen with a new increase from 2004 due to the local government urban regeneration policies mentioned above. As a consequence, the urban landscape of Ciutat Vella shows contrasts between old and new buildings (see figure 6).

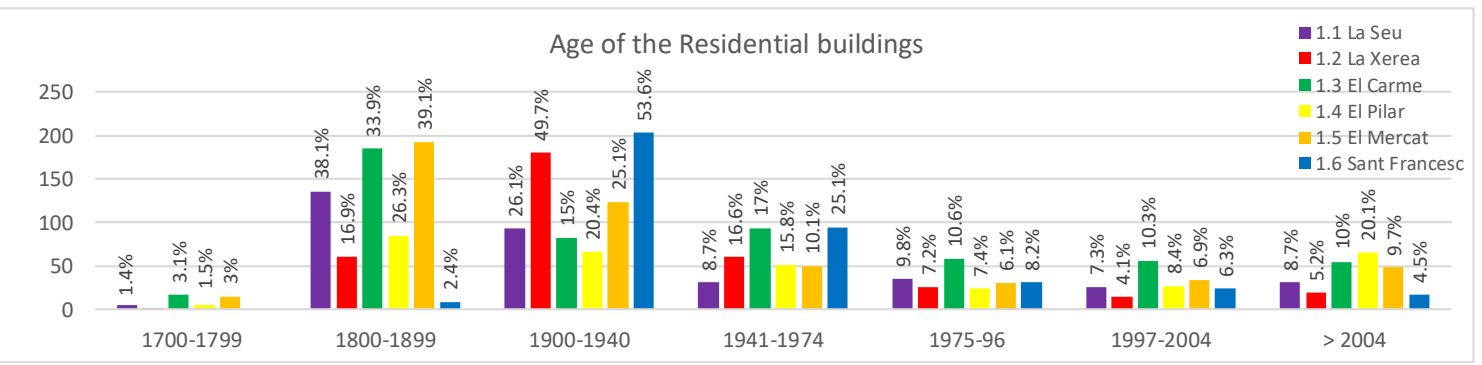

Fig. 5 Age of the residential buildings (Cadrastal database 2017)

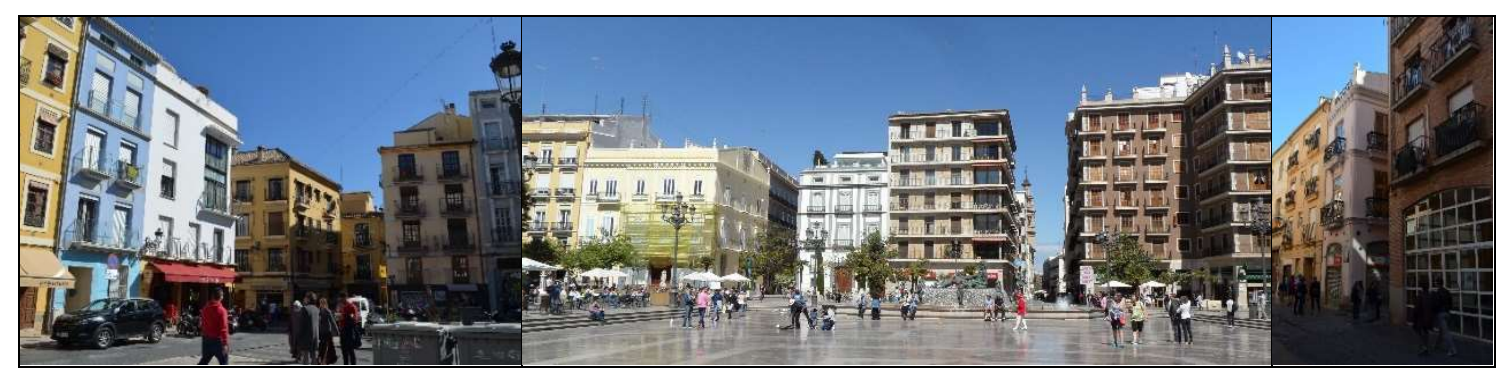

Fig. 6 Urban landscape in Ciutat Vella (credit: the authors) 
The number of storeys of the residential buildings varies from 1 to 21 (only 5 with more than 12), most of them having 4 and 5 storeys, except in Sant Francesc, where circa 25\% exceeding 8 storeys (figure 7).

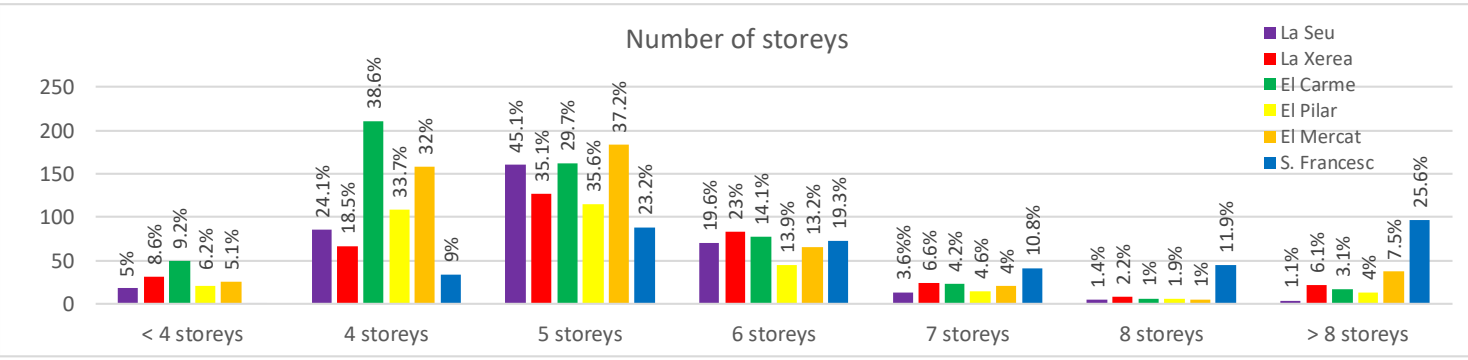

Fig. 7 Number of storeys

The most common construction system in Ciutat Vella (69\% of buildings) consists of unreinforced brick masonry load-bearing walls (URM) with one-way floors with timber (figure 8) or steel beams and joists with brick vaults infills (figure 9 ). $9 \%$ of these buildings have been retrofitted in different levels, from reinforcing the timber floors with concrete slabs to replacing the internal structural systems with new concrete frames maintaining the façades without bearing function (Mileto C., Vegas F. 2005, Ros et al. 2002). In some of these buildings, there are cast iron columns in the ground floor to obtain an open floor plan, thus reducing the building stiffness and creating a soft story (figure 10)

Additionally, 26\% of the residential buildings have reinforced concrete framed structures with mostly one-way concrete joists floors and only $5 \%$ have a steel framed structure with masonry infill walls (see figure 11)
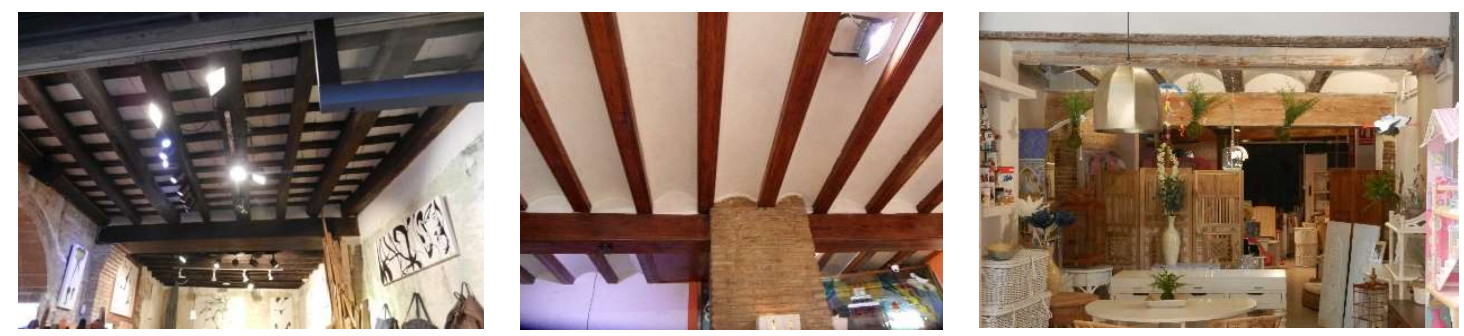

Fig. 8 URM with one-way floors, timber beams and joists (credit: the authors)
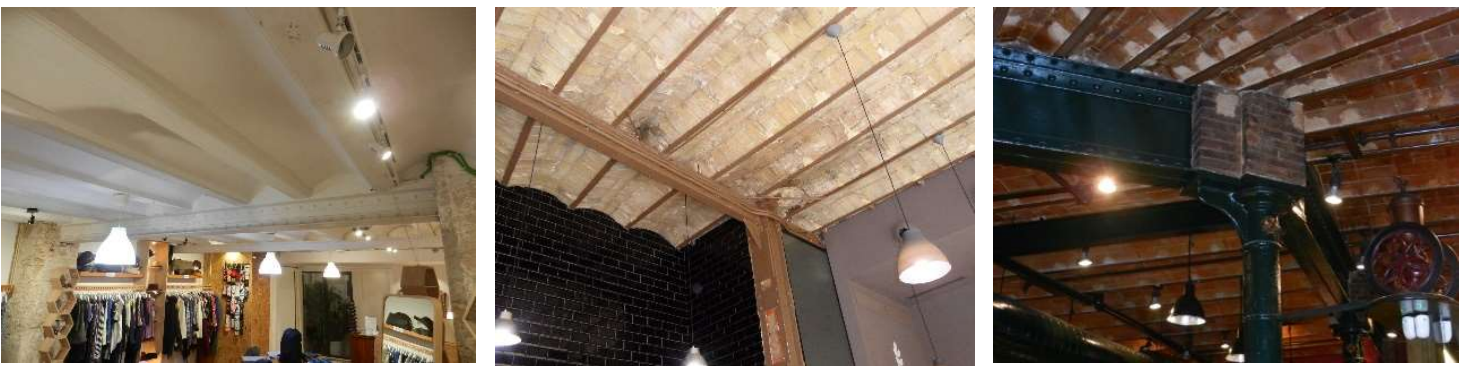

Fig. 9 URM with one-way floors, steel beams and joists (credit: the authors)
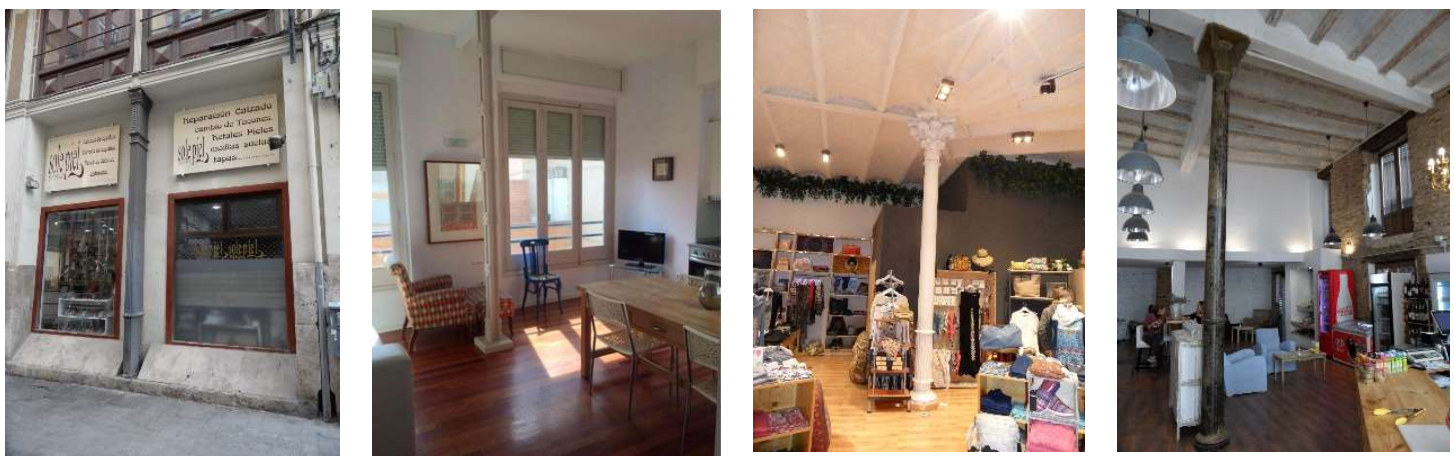

Fig. 10 Cast iron columns (credit: the authors) 


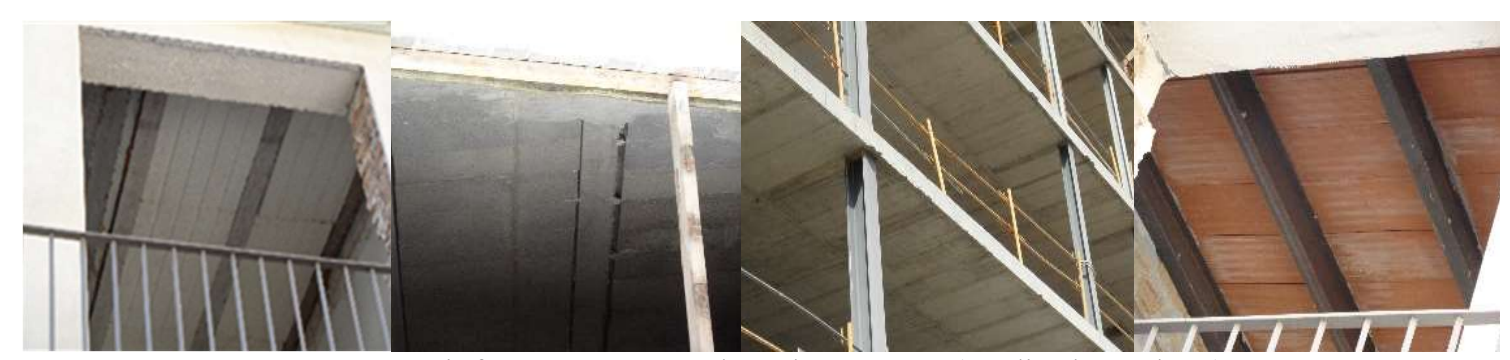

Fig. 11 Reinforce concrete and steel structures (credit: the authors)

The identified structural typologies are classified, according to the Building Typology matrix (BTM) proposed by Risk-UE (Milutinovic and Trendafiloski 2003). Table 1 shows BTM in Ciutat Vella.

. Table 1. Building Typology Matrix in Ciutat Vella

\begin{tabular}{|c|l|l|}
\hline $\begin{array}{c}\text { STRUCTURAL } \\
\text { MATERIALS }\end{array}$ & TYPOLOGY & \\
\hline MASONRY & M 3.1 & $\begin{array}{l}\text { unreinforced masonry bearing walls with floors made with timber joists and } \\
\text { brick vaults }\end{array}$ \\
\cline { 2 - 3 } & M 3.3 & $\begin{array}{l}\text { unreinforced masonry bearing walls with floors made with steel joists and } \\
\text { brick vaults }\end{array}$ \\
\cline { 2 - 3 } & M 3.4 & bearing walls with concrete joists floors \\
\cline { 2 - 3 } & M 4 & Reinforced or confined masonry bearing walls \\
\cline { 2 - 3 } & M 5 & Overall strengthened masonry buildings \\
\hline CONCRETE & RC1 & Concrete moment frames \\
\cline { 2 - 3 } & RC3.2 & irregular concrete frames with masonry infill walls \\
\hline \multirow{2}{*}{ STEEL } & S1 & Steel Moment Frames \\
\cline { 2 - 3 } & S3 & Steel frame with masonry infill walls \\
\cline { 2 - 3 } & S5 & Steel and reinforced concrete composite system (3 buildings only, not included in the study). \\
\hline
\end{tabular}

The distribution of the structural typologies in total in Ciutat Vella and itemised in each neighbourhood is shown in figures 12 and 13 respectively. It is worth noting that, except in Sant Francesc, more than 50\% are M3.1.

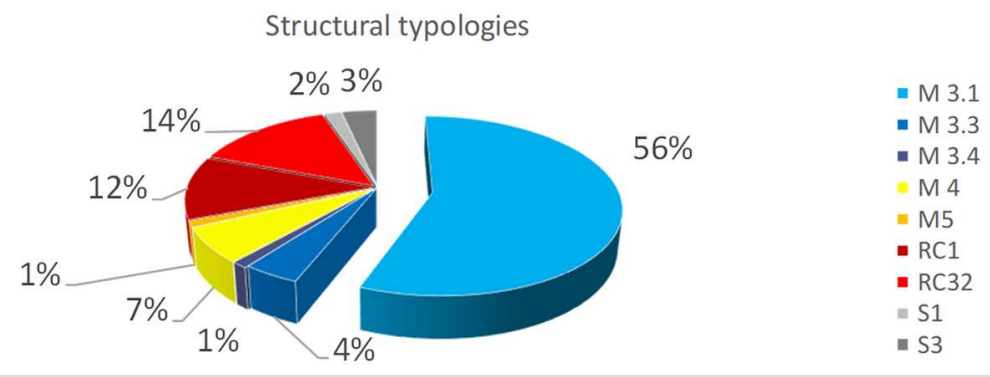

Fig. 12 Distribution of the structural typologies in percentage in Ciutat Vella

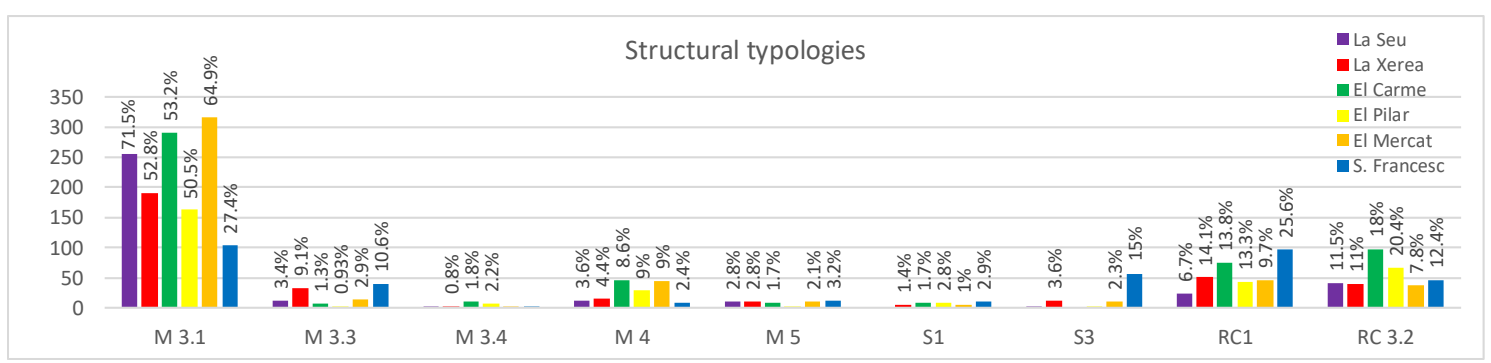

Fig. 13 Structural typologies of the residential buildings in each neighbourhood

Figure 14 shows, in green, all the residential buildings which structural typology and construction system have been verified by the authors (about 50\% of the residential buildings). Buildings in grey correspond to residential buildings which structural typology have been inferred from the age, while the ones in white are non-residential buildings, ruins or empty plots. 


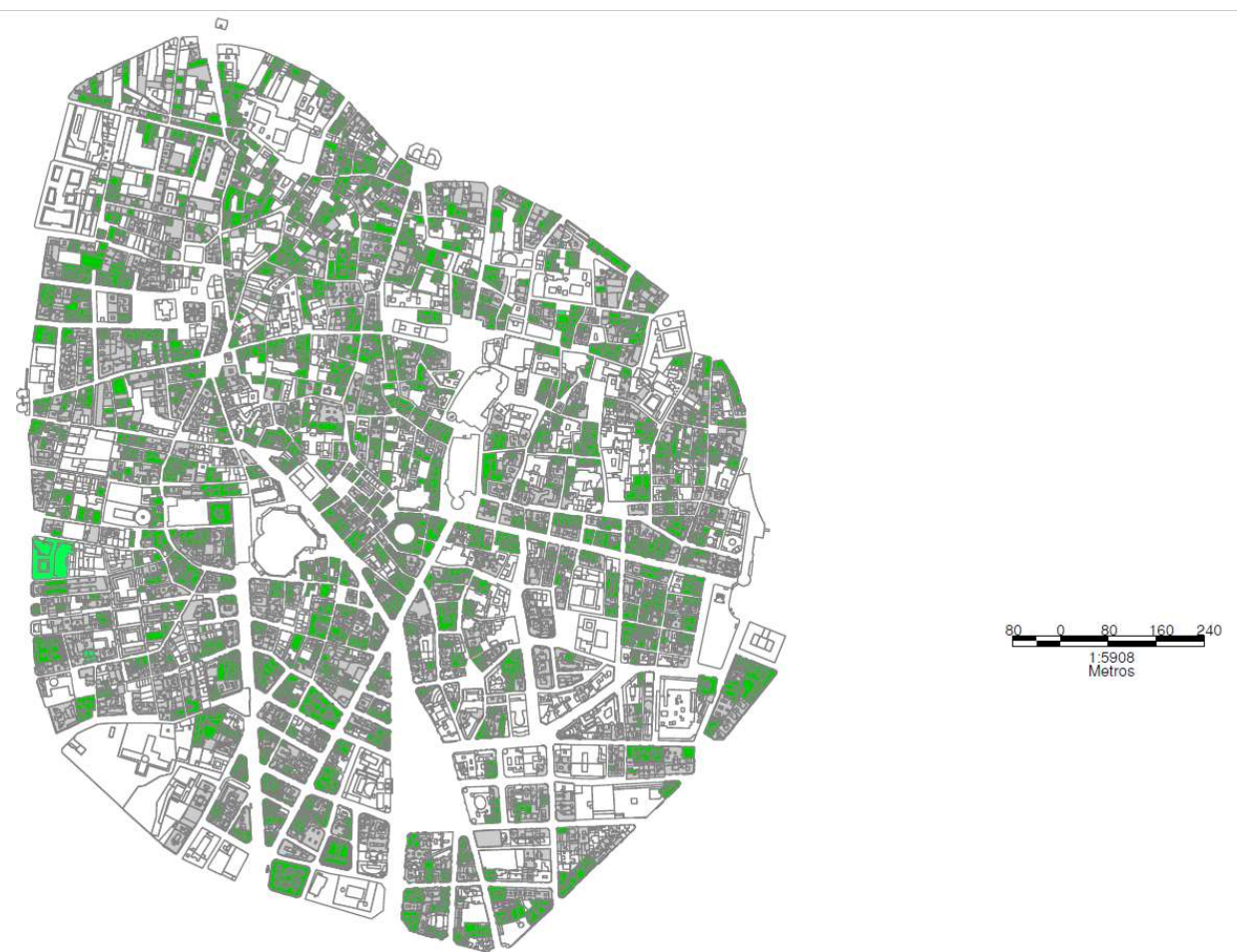

Fig. 14 Verified structural typologies in Ciutat Vella

Given the evolution of the constructive recommendations and technical standards in Spain, determining factors in the construction quality and the seismic response, the buildings in Ciutat Vella have been grouped into the following seven constructive periods (Guardiola-Víllora and Basset-Salom, 2015).

1. prior to 1940 (59.3\% of the residential buildings). This first period is characterized by the absence of technical regulations, being the prevailing structural typology load-bearing unreinforced masonry walls without any orthogonal bracing, designed exclusively to resist gravitational loads and with a deplorable quality of execution. It was common practice to find projects without any technical project manager despite, since the mid-nineteenth century, the first urban police ordinances of Valencia required the signature of a qualified technician for any construction work.

2. 1941-1962 (8\% of the residential buildings): After the Spanish civil war the reinforced concrete framed structures were the most common, being the country ruled under autarkic policies their design was regulated by the first antecedent of the Spanish technical regulations: "Regulation on restrictions of iron for buildings" (BOE 02/08/1941). This document established the "Technical standards of knowledge and unavoidable application" to be considered in the calculation and execution of any construction using iron, including, among other recommendations, to prevent the use of compression rebars in beams.

3. 1963-1968 (4.7\% of the residential buildings): The publication of the standard MV 101 "Actions on Buildings" (BOE 9/02/1963) defined the beginning of the third period, including, for the first time, the seismic actions to be considered in towns with seismic grade $\geq$ VII (not applicable in Valencia with seismic grade V). In addition, the above mentioned "Regulation on restrictions of iron for buildings" was repealed, leading to an improvement in the quality of materials and design of reinforced concrete structures compared to the previous period.

4. $1969-1974$ (2.5\% of the residential buildings): This period starts after the publication of the first seismic standard "Earthquake Resistant Standard" PGS-1 (BOE 4/02/1969), document which, without any design recommendations, included very basic requirements in terms of static calculation, establishing the facultative application of the seismic actions in Valencia (zone classified as low seismicity). It is worth considering that the publication of the MV standards, namely MV 201-1972 (Brick Resistant Walls) or MV 103-1972 (Structural Analysis of Building Steel Structures), among others, favoured the improvement in the design and execution of the structures at that time.

5. 1975-1996 (8.2\% of the residential buildings): This period, is defined by the Seismic Standard PDS1 (BOE 21/11/1974), which addressed more systematically the structural analysis considering 
seismic actions. However, being the seismic hazard map essentially the same as the previous one of 1968, to consider seismic actions in Valencia (zone of low seismicity) was not compulsory. Furthermore in 1977, the old MV standards were transformed into the new Basic Construction Standards (NBE), a mandatory code leading to a higher control and to an improvement of the quality of the constructive process. It was in this period when the first urban regeneration policies in Ciutat Vella (RIVA PLAN 1992-1997) promoted retrofitting and rebuilding processes.

6. 1997-2004 (7.3\% of the residential buildings): The beginning of the sixth period started in 1997, considering the two-year transition period to the new Spanish Code for Seismic Design of Buildings NCSE 94 (BOE 08/02/95). This document entailed a significant qualitative improvement, establishing in addition to new calculation parameters, design and constructive prescriptions. The application of the standard was mandatory for normal importance buildings in areas where the basic seismic ground acceleration $\left(\mathrm{a}_{\mathrm{b}}\right)$ was equal o bigger than $0.06 \mathrm{~g}$. That fact implied for the city of Valencia $\left(a_{b}=0.06 \mathrm{~g}\right)$ the obligation to calculate the structures considering seismic actions and to comply with all the code requirements.

7. After 2004 (9.5\% of the residential buildings): the last period started two years after the publication of the Spanish Code for Seismic Design of Buildings NCSE 02 (BOE 11/10/2002), mandatory for the city of Valencia as well as the previous one.

\section{SEISMIC VULNERABILITY ASSESSMENT}

The seismic vulnerability of a structure is its susceptibility to suffer a certain degree of damage in case of occurrence of a given seismic event. Therefore, the vulnerability index (VI) quantifies the seismic performance of buildings, higher values corresponding to the most vulnerable ones.

The vulnerability of Ciutat Vella District residential buildings has been assessed, as mentioned in section 1, with the Risk-UE level 1 VIM (Milutinovic and Trendafiloski 2003), which assigns, to each building structural typology, the most likely vulnerability index $\mathrm{VI}^{*}$, the endpoints of the plausible interval $[\mathrm{VI}-; \mathrm{VI}+]$ together with the lower and upper bounds of the possible values [VI ${ }^{\min }$; VI $\left.{ }^{\max }\right]$ (Giovinazzi y Lagomarsino, 2004).

Table 2 shows the values of the Vulnerability Indices for the residential building typologies in Ciutat Vella, according to their type of structure and construction materials, defined in the RISK-UE project (Milutinovic and Trendafiloski 2003).

Table 2 Vulnerability Indices for the residential building typologies in Ciutat Vella (Milutinovic and Trendafiloski, 2003)

\begin{tabular}{|l|r|r|r|r|r|}
\hline Typology & VI $^{\text {min }}$ & VI- & VI $^{*}$ & VI+ & VI $^{\text {max }}$ \\
\hline M 3.1 & 0.460 & 0.650 & 0.740 & 0.830 & 1.020 \\
\hline M 3.3 & 0.460 & 0.527 & 0.704 & 0.830 & 1.020 \\
\hline M 3.4 & 0.300 & 0.490 & 0.616 & 0.793 & 0.860 \\
\hline M 4 & 0.140 & 0.330 & 0.451 & 0.633 & 0.700 \\
\hline M 5 & 0.300 & 0.490 & 0.694 & 0.953 & 1.020 \\
\hline RC1 & -0.020 & 0.047 & 0.442 & 0.800 & 1.020 \\
\hline RC 3.2 & 0.060 & 0.127 & 0.522 & 0.880 & 1.020 \\
\hline S1 & -0.020 & 0.467 & 0.363 & 0.640 & 0.860 \\
\hline S3 & 0.140 & 0.330 & 0.484 & 0.640 & 0.860 \\
\hline
\end{tabular}

The final vulnerability index, VI (eq 1) is particularized for each individual building by adding to the typological vulnerability index ( $\left.\mathrm{VI}^{*}\right)$ a regional modifier, $\Delta \mathrm{VR}$, and a set of behaviour modifiers, $\Delta \mathrm{Vm}$, which consider factors affecting the building seismic vulnerability.

$$
\mathrm{VI}=\mathrm{VI}^{*}+\Delta \mathrm{VR}+\Delta \mathrm{Vm}
$$

The regional modifier, $\Delta \mathrm{VR}$, considers the specific quality of the building at regional level according to the date of construction and the building and seismic design codes in force at that moment. The value has been quantified for each construction period, taking into account the technical, structural and constructive information given in section 2. Periods prior to 1968 are characterised by poor construction practices and absence or very basic national regulations. In the following periods, construction was regulated by the seismic standards PGS-1 (1968) and PDS-1 (1974) including very basic designing rules 
and lack of design requirements. With the approval of the standards NCSE 94 (1995) and NCSE 02 (2002), the seismic design of buildings in Spain has improved considerably, being mandatory to include the seismic loads in the structural analysis and design of every structure.

Table 3 shows the regional modifiers for the building typologies in Ciutat Vella. These coefficients have been defined from the Barcelona regional modifiers proposed by Lantada (2007) and Lantada et al. (2010) adapted for L'Eixample district in Valencia by Guardiola-Víllora and Basset-Salom (2015), as well as from the studies of the performance of masonry and RC buildings damaged during Lorca May $11^{\text {th }} 2011$ earthquake (Feriche et al. 2012, Basset-Salom and Guardiola-Víllora 2014, Martinez-Cuevas and GasparEscribano 2016).

Table 3 Regional modifiers, $\triangle \mathrm{VR}$ for the building typologies in Ciutat Vella

\begin{tabular}{|l|r|r|r|r|r|r|}
\hline & \multicolumn{7}{|c|}{ TYPOLOGY } \\
\hline PERIOD & M3.1 & M3.3 & M3.4 & M4/M5 & S1-S3 & RC1-RC3.2 \\
\hline$<1940$ & 0.120 & 0.234 & 0.134 & 0.08 & 0.234 & 0.228 \\
\hline $1941-1962$ & 0.100 & 0.171 & 0.134 & 0.08 & 0.171 & 0.228 \\
\hline $1963-1968$ & 0.080 & 0.109 & 0.134 & 0.08 & 0.109 & 0.228 \\
\hline $1969-1974$ & 0.010 & 0.046 & 0.009 & 0.08 & 0.046 & 0.100 \\
\hline $1975-1996$ & -0.052 & -0.016 & -0.053 & 0.08 & -0.016 & 0.100 \\
\hline $1997-2004$ & & & & 0.08 & -0.080 & 0.080 \\
\hline$>2004$ & & & & 0.08 & -0.080 & 0 \\
\hline
\end{tabular}

The behaviour modifiers, $\Delta \mathrm{Vm}$, take into account the contribution to the vulnerability index of factors related to the building itself and to its location within in the block, therefore their applicability depends strongly on the level of detailed information available for the building stock. This information was collected from all the sources mentioned in section 1 and from the field survey carried out to complete and improve the data retrieved from them.

The modifiers considered in Risk-UE level 1 VIM (Milutinovic and Trendafiloski 2003) refer to the state of preservation or maintenance, structural system, code level, number of floors, geometric and stiffness irregularities, aggregate building position and elevation, retrofitting interventions, aseismic devices, soil morphology (slope or cliff) and foundation, as well as type and quality of materials (masonry or RC buildings). The definition, calibration and quantification of these modifiers (and new ones such as the façade length), have been adjusted by different authors (Giovinazzi and Lagomarsino 2004; Giovinazzi 2005; Lantada 2007; Lantada et al. 2010; Feriche et al. 2012; Tomás et al 2017; Martinez-Cuevas et al. 2017), based on the seismic response and the level of damage of both masonry and RC residential buildings in recent earthquakes. Major changes include the influence of short columns and soft storeys.

Soil morphology modifiers (slope or cliff) are not applicable in Ciutat Vella. Behaviour modifiers accounting for geometric and structural features as well as for building location have been considered to obtain the vulnerability index VI of the residential buildings in Ciutat Vella. Modifiers related to foundation, aseismic devices or code level have been considered in the regional modifiers

Geometric irregularities both in plan (horizontal irregularity) and elevation (vertical irregularity) influence the vulnerability of buildings. According to Lantada (2007) the horizontal irregularity modifier, based on the compactness ratio rc (relating the area of the building and the area of the circle with the same perimeter), takes the value of $+0,04$ when $\mathrm{rc}<0,5$ and $+0,02$ when $0,5 \leq \mathrm{rc} \leq 0,7$. The modifier considering the irregularity in elevation $(+0.04$ when $\delta>3$ and +0.02 when $1<\delta<3)$ is calculated from the coefficient $\delta$ which represents the difference between the maximum number of floors in the existing building and the number of floors of another building with the same volume and plan area.

The number of storeys above ground is a factor which penalises or improves the building performance. Table 4 shows the values for the height modifier (Lantada 2007) depending on the structural typology and the age of the building.

Table 4 Height modifier factor

\begin{tabular}{|l|l|c|c|}
\hline Typology & $\mathrm{N}^{\circ}$ storeys above ground & $\leq 1940$ & $>1940$ \\
\hline Masonry & Low: $(1-2)$ & -0.02 & -0.04 \\
M 3.1 M 3.3 M 3.4 & Medium (3-5) & +0.02 & 0 \\
M 4 and M 5 & High $(\geq 6)$ & +0.06 & +0.04 \\
\hline RC and Steel frames & Low (1-3) & -0.04 & -0.04 \\
RC1 RC3.2 & Medium (4-7) & 0 & 0 \\
S1 S3 & High $(\geq 8)$ & +0.08 & +0.08 \\
\hline
\end{tabular}


The existence of long masonry façades without perpendicular stiffening can cause their collapse, due to the lack of connexion with the load-bearing internal walls. A length modifier (Lantada 2007) has been considered for masonry buildings with façades longer than $15 \mathrm{~m}$ (25\% of the non-retrofitted masonry building stock).

Stiffness irregularities (soft storey and short column) have proved to be relevant in the seismic response of buildings during Lorca $11^{\text {th }}$ May earthquake (Feriche et al. 2012; Martinez-Cuevas et al. 2017; Tomás et al 2017). The modifier adopted for masonry buildings with soft story is +0.04 (Milutinovic and Trendafiloski 2003, Feriche et al. 2012) and +0.2 for RC and Steel buildings (Tomás et al 2017). Figure 15 shows the number and percentage of buildings with soft story per typology in Ciutat Vella. Buildings with short column (only 2 buildings in Ciutat Vella) have been penalised with +0.08 (Feriche et al. 2012)

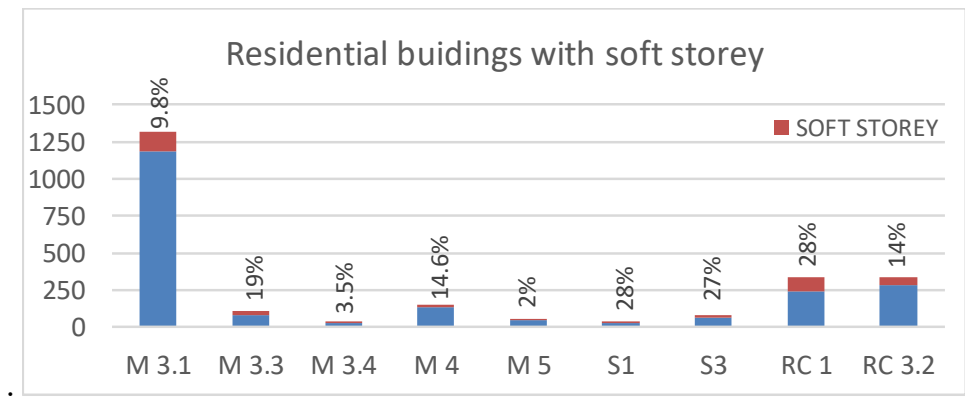

Fig. 15 Number and percentage of buildings with soft story in Ciutat Vella

Notwithstanding the influence of construction techniques, the state of preservation is a determinant factor in lowering vulnerability of structures in historic city centres and in improving their seismic performance, specially in the case of unreinforced masonry buildings (Basset-Salom and Guardiola-Víllora 2013) therefore a modifier accounting for the state of preservation has been considered $(+0.04$ when buildings need major repairs and -0.04 when there are not needed, as in Lantada 2007)

The aggregate building position (relative position of the building in plan with respect of the rest of the buildings in the same block) is another determinant factor to be considered. Being the corner and header buildings the most vulnerable, the values assigned to this modifier are +0.06 (header), $+0,04$ (corner) and -0.04 (middle) (Lantada 2007). Noteworthy is the situation of the buildings which, although located in the middle of the block, are adjacent to a long-term empty plot (see Figure 16). These buildings have been considered as corner or header buildings. Moreover, the aggregate building elevation modifier takes into account the difference in height with adjacent buildings, when greater than or equal to two floors. Values range from -0.04 to +0.04 (Lantada et al. 2010).
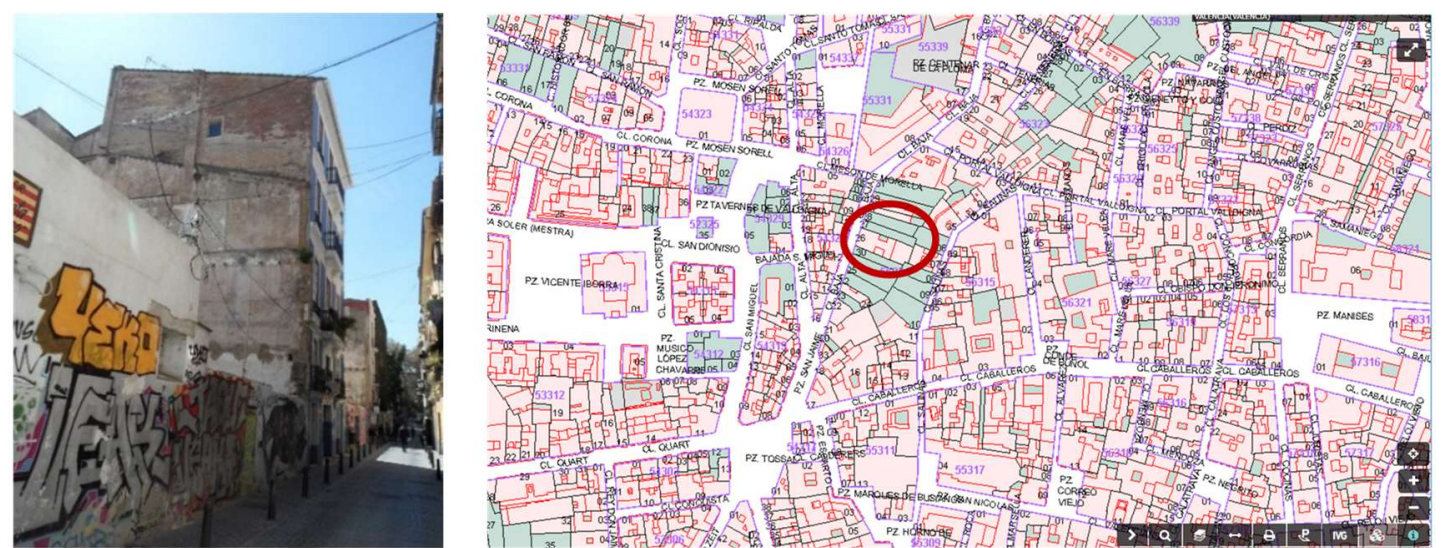

Fig. 16 Building adjacent to empty plots. Location in the cadastral plan (empty plots in green)

All the data have been implemented in a database, determining, from the structural typology, the most likely vulnerability index $\mathrm{VI}^{*}$ and, depending on the characteristics of the building, the corresponding regional and behaviour modifiers. These values have been added to the buildings attribute table, linked to the corresponding gvSIG (gvSIG association 2009) mapping tool.

The vulnerability indices of masonry buildings (M3.1, M3.3 and M3.4) range from 0.556 to 0.929 , for retrofitted masonry buildings (M4 and M5) from 0.391 to 0.774 ; for reinforced concrete buildings (RC1 
and RC3.2) from 0.382 to 0.802 and for steel buildings (S1 and S3) from 0.303 to 0.764 , being the most vulnerable buildings those located at the headers of the block, as expected.

This vulnerability index distribution shows the low seismic quality of the dwellings in Ciutat Vella, which is typical for historical city centres located in areas with low to moderate hazard, due to a lack of concern for seismic-resistant design and protection.

Residential buildings are classified into one of the six vulnerability classes (A - F) from the EMS-98 scale (Grünthal 1998) according to their vulnerability index and the vulnerability membership functions (Milutinovic and Trendafiloski 2003) for $\chi=0.5$ (which defines the interval for plausible vulnerability indices VI-; VI+) (figure 17).

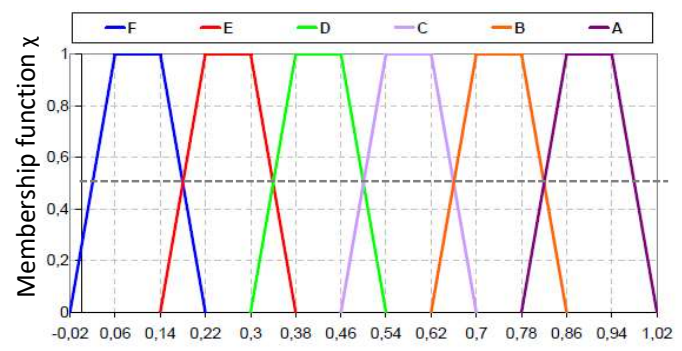

Vulnerability Index VI

Fig. 17 Vulnerability Index membership functions $\chi$ for EMS 98 vulnerability classes (Milutinovic and Trendafiloski 2003)

The majority of the buildings $(61 \%)$ have a final vulnerability index (sum of the representative value and all the modifiers) within the interval $[0.66<\mathrm{VI} \leq 0.82]$ corresponding to vulnerability class $\mathrm{B}$. The percentage of the buildings corresponding to classes A, C, D and E are $3.5 \%, 17 \%, 18 \%$ and $0.5 \%$ respectively,

The most vulnerable neighbourhood is El Mercat with $4.5 \%$ of vulnerability class A buildings and $70.1 \%$ class B. The neighbourhood with the higher percentage of classes C and D (less vulnerable) is Sant Francesc (with more new buildings designed to comply with recent seismic codes). Noteworthy is the percentage of buildings class D in El Carmen, directly related with the replacement and retrofitting of many buildings following the policy of urban regeneration. Figure 18 includes some of the buildings with the highest vulnerability indices.

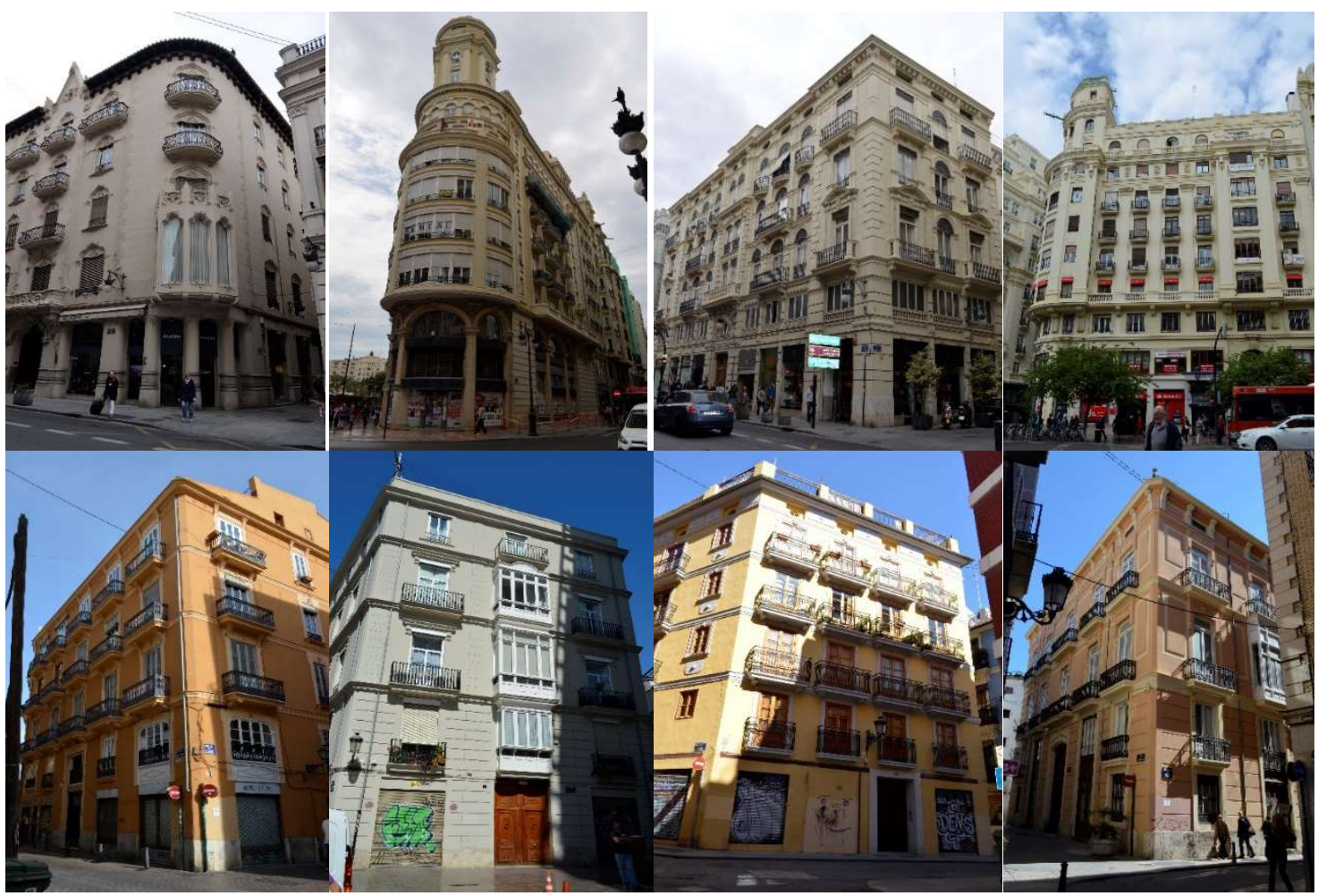

Fig. 18 Buildings in Ciutat Vella with the highest vulnerability indices (credit: the authors) 
Maps representing the seismic vulnerability index and vulnerability class of each building in Ciutat Vella are shown in Figures 19 and 20 respectively. The percentages as well as the number of buildings with respect to each neighbourhood are also included.
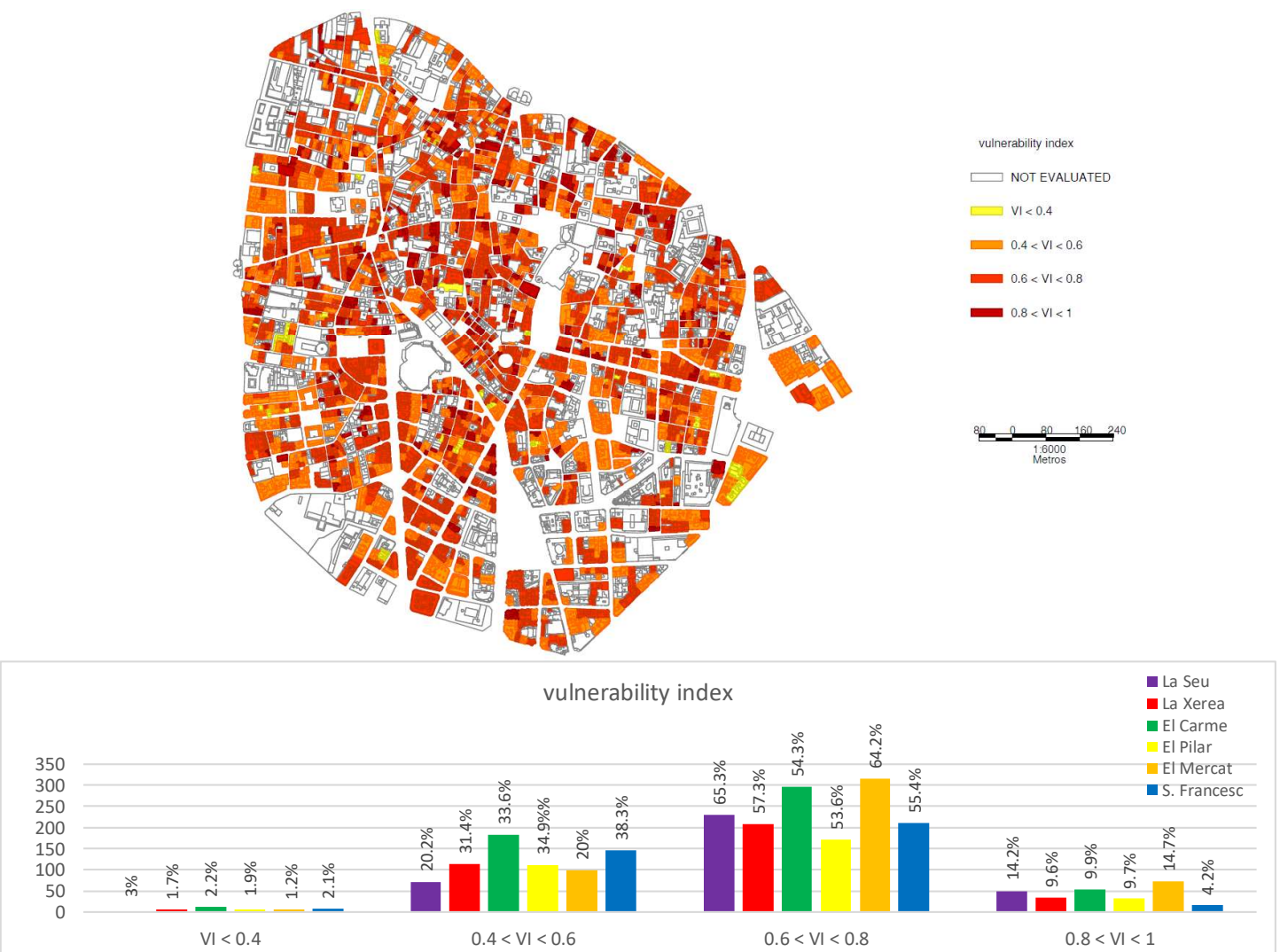

Fig. 19 Map of Vulnerability Indices of residential buildings in Ciutat Vella. Vulnerability indices in each neighbourhood (number of buildings and percentage with respect to each neighbourhood)
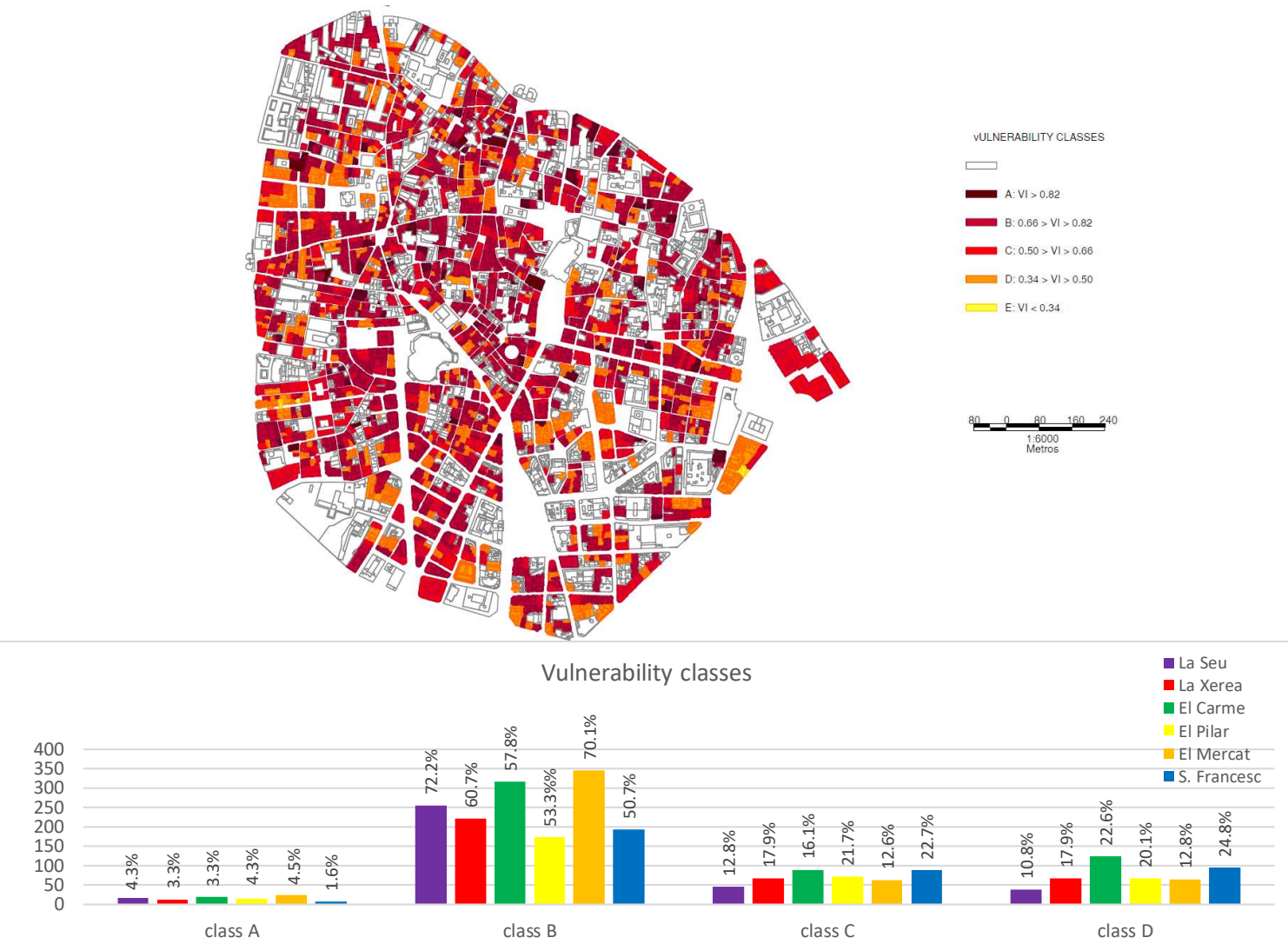

Fig. 20 Map of Vulnerability classes according to EMS-98. Vulnerability Classes in each neighbourhood (number of buildings and percentage with respect to each neighbourhood) 


\section{SEISMIC HAZARD SCENARIOS}

A deterministic and two probabilistic seismic hazard scenarios have been considered in this study.

The intensity corresponding to the deterministic scenario was taken from the largest historical earthquake recorded, near the city of Valencia, that is the strongest closest event that has ever affected the site. This reference earthquake corresponds to the 1872 Carlet Earthquake with an EMS-98 intensity of VII (Giner et al. 2003).

The probabilistic earthquake scenarios were defined based on the information provided by the regional maps of expected seismic intensity including soil effects (Figure 21) for a return period of 500 years (URSUA 2010). There are 3 different zones in Valencia, being the expected intensity, for a return period of 500 years, 6-6.5, 6.5-7 and 7-7.5, respectively (the Valencian Community plan of seismic risk establish an intensity 7.5 for the entire municipality).
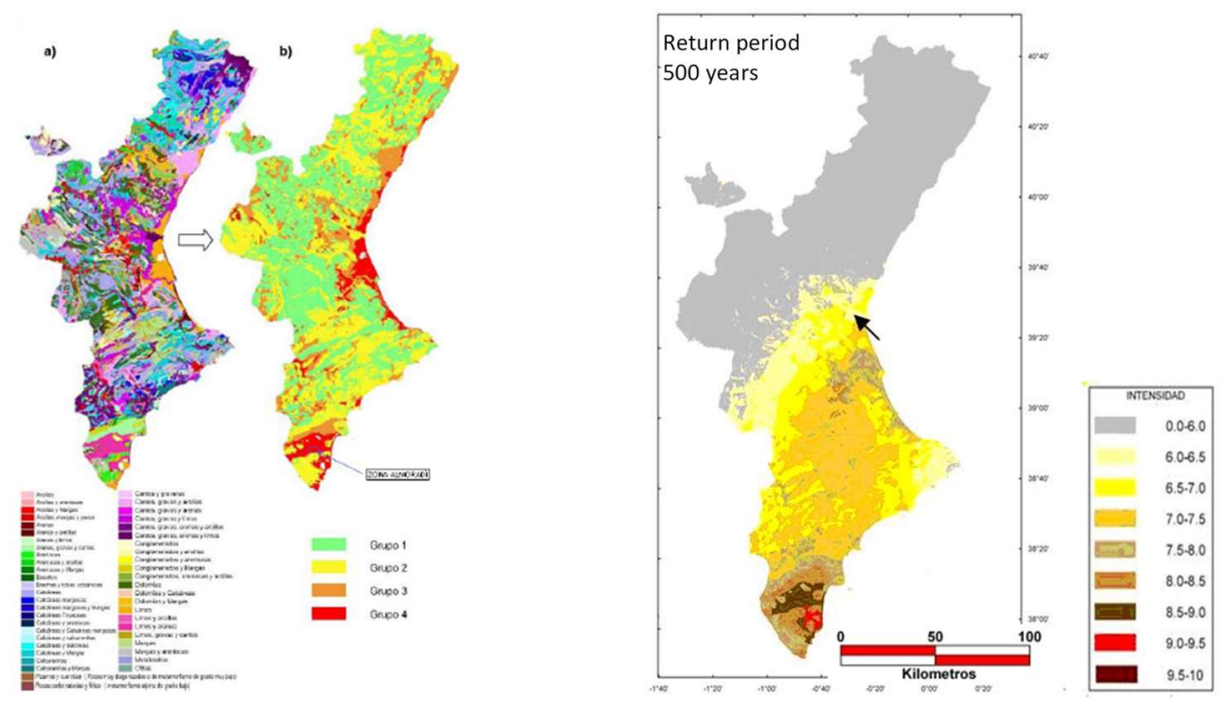

Fig. 21 A) Lytology map, b) Soil classification c) Maps of expected seismic intensity in Valencian Comunity for a return period of 500, including soil effects (URSUA, 2010)

A study estimating local site effects was carried out in Ciutat Vella District by Franklin et al. (2006) suggesting that some areas are susceptible only to low ground motion amplification, due to the characteristics of the spectrum. Being irrelevant, these effects haven't been considered.

Therefore, the following scenarios are proposed: a deterministic scenario (intensity VII) and two probabilistic scenarios (with intensity 6 and 7.5, minimum and maximum respectively) for the entire district. The NCSE-02 standard assigns to Valencia a basic acceleration of $0.04 \mathrm{~g}$, which corresponds to an intensity VI, according to the relation between both quantities established in the NCSE-94, keeping the adopted values on the safe side.

\section{SEISMIC DAMAGE SCENARIOS}

The expected seismic damage of every building is characterized by the mean damage grade $\mu_{D}$, ranging from 0 to 5 (labelled as No damage/undamaged, Slight, Moderate, Substantial to Heavy, Very Heavy and Destruction), according to the European Macro-seismic Scale EMS-98 (Grünthal 1998).

The mean damage grade is obtained with a semi-empirical vulnerability function (Giovinazzi 2005) from the vulnerability index VI and the macroseismic intensity I (equation 2).

$$
\mu_{D}=2,5 \cdot\left[1+\tanh \left(\frac{I+6,25 \cdot V I-13,1}{Q}\right)\right]
$$

where $Q$ is the ductility index evaluated according to the building typology and the constructive characteristics (Lagomarsino and Giovinazzi 2006), taking the value 2.3 for residential buildings. 
The distribution of damage probability is defined by using a binomial-equivalent beta probability density function. For the beta function to be equivalent to the binomial function (eqs 3 and 4), parameters $\mathrm{t}$ and $\mathrm{r}$ have been adjusted, defining $t=8$ and $r=t\left(0.007 \mu_{D}^{3}-0.0525 \mu_{D}^{2}+0.2875 \mu_{D}\right)$ (Giovinazzi 2005)

$$
\begin{array}{lll}
\text { Binomial function: } & p_{B}(k)=\frac{5 !}{k !(5-k) !}\left(\frac{\mu_{D}}{5}\right)^{k}\left(1-\frac{\mu_{D}}{5}\right)^{5-k} & k=0,1,2,3,4,5 \\
\text { Beta function: } & p_{\beta}(x)=\frac{\Gamma(t)}{\Gamma(r) \Gamma(t-r)} \frac{(x-a)^{r-1}(b-x)^{t-r-1}}{(b-a)^{t-1}} & a \leq x \leq b \quad a=0 \quad b=6
\end{array}
$$

By assuming a beta cumulative density function (eq 5), the probability (eq 6) associated to each damage grade $\mathrm{k}(\mathrm{k}=0,1,2,3,4,5)$ for each seismic scenario (intensity 6,7 or 7.5$)$ is calculated, obtaining the damage probability matrices (DPM) for each neighbourhood and building typology in Ciutat Vella District (see table 5 /figure 22).

The column graphs in figure 23 illustrate the probable distribution of damage grades (D0: No damage, D1: Slight, D2: Moderate D3: Substantial to Heavy, D4: Very Heavy, D5: Destruction) in the building stock of each neighbourhood, for each seismic intensity.

$$
\begin{aligned}
& P_{\beta}(k)=\int_{0}^{x} p_{\beta}(y) d y \\
& p(k)=\int_{k}^{k+1} p_{\beta}(y) d y=P_{\beta}(k+1)-P_{\beta}(k)
\end{aligned}
$$

Finally, a weighted mean damage index, $D S m,(7)$ is calculated from the probability of occurrence of each damage grade, $P\left[D S_{k}\right], k$ taking values from 0 to 5 (see table 5).

$$
D S_{m}=\sum_{k=0}^{5} k \cdot P\left[D S_{k}\right]
$$

\begin{tabular}{|c|c|c|c|c|c|c|c|c|c|c|c|}
\hline \multicolumn{4}{|c|}{ LA SEU } & \multirow[b]{2}{*}{$\mu \mathrm{d}$} & \multicolumn{6}{|c|}{ Probability of each damage grade } & \multirow{2}{*}{$\mathrm{DSm}$} \\
\hline & Typology & \multicolumn{2}{|c|}{ VI } & & D0 & D1 & D2 & D3 & D4 & D5 & \\
\hline \multirow{6}{*}{ 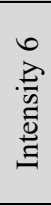 } & \multirow{2}{*}{$\begin{array}{l}\text { M 3.1 } \\
71.5 \% \\
\end{array}$} & $\min$ & 0.6600 & 0.3499 & 0.8132 & 0.1538 & 0.0292 & 0.0036 & 0.0002 & 0.0000 & 0.2238 \\
\hline & & $\max$ & 0.8526 & 0.8824 & 0.4225 & 0.3820 & 0.1553 & 0.0364 & 0.0037 & 0.0001 & 0.8169 \\
\hline & \multirow{2}{*}{$\begin{array}{l}\text { RC1 } \\
6.7 \% \\
\end{array}$} & $\min$ & 0.4020 & 0.0909 & 0.9677 & 0.0285 & 0.0035 & 0.0003 & 0.0000 & 0.0000 & 0.0365 \\
\hline & & $\max$ & 0.5220 & 0.1716 & 0.9281 & 0.0622 & 0.0088 & 0.0009 & 0.0000 & 0.0000 & 0.0825 \\
\hline & \multirow{2}{*}{$\begin{array}{l}\text { RC3.2 } \\
11.5 \% \\
\end{array}$} & $\min$ & 0.4620 & 0.1251 & 0.9521 & 0.0420 & 0.0055 & 0.0005 & 0.0000 & 0.0000 & 0.0544 \\
\hline & & $\max$ & 0.6020 & 0.2602 & 0.8749 & 0.1058 & 0.0174 & 0.0019 & 0.0001 & 0.0000 & 0.1465 \\
\hline \multirow{6}{*}{ 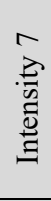 } & \multirow{2}{*}{$\begin{array}{l}\text { M 3.1 } \\
71.5 \% \\
\end{array}$} & $\min$ & 0.6600 & 0.7610 & 0.5041 & 0.3482 & 0.1207 & 0.0247 & 0.0022 & 0.0000 & 0.6727 \\
\hline & & $\max$ & 0.8526 & 1.6915 & 0.1015 & 0.3402 & 0.3408 & 0.1750 & 0.0406 & 0.0018 & 1.7185 \\
\hline & \multirow{2}{*}{$\begin{array}{l}\text { RC1 } \\
6.7 \% \\
\end{array}$} & $\min$ & 0.4020 & 0.2115 & 0.9053 & 0.0811 & 0.0123 & 0.0013 & 0.0001 & 0.0000 & 0.1097 \\
\hline & & $\max$ & 0.5220 & 0.3909 & 0.7832 & 0.1762 & 0.0357 & 0.0047 & 0.0003 & 0.0000 & 0.2626 \\
\hline & \multirow{2}{*}{$\begin{array}{c}\text { RC3.2 } \\
11.5 \% \\
\end{array}$} & $\min$ & 0.4620 & 0.2884 & 0.8563 & 0.1206 & 0.0207 & 0.0024 & 0.0001 & 0.0000 & 0.1695 \\
\hline & & $\max$ & 0.6020 & 0.5791 & 0.6391 & 0.2741 & 0.0737 & 0.0122 & 0.0009 & 0.0000 & 0.4616 \\
\hline \multirow{6}{*}{ 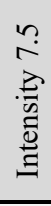 } & \multirow{2}{*}{$\begin{array}{l}\text { M 3.1 } \\
71.5 \% \\
\end{array}$} & $\min$ & 0.6600 & 1.0855 & 0.3062 & 0.4097 & 0.2139 & 0.0621 & 0.0079 & 0.0002 & 1.0563 \\
\hline & & $\max$ & 0.8526 & 2.2063 & 0.0347 & 0.2190 & 0.3546 & 0.2801 & 0.1032 & 0.0084 & 2.2233 \\
\hline & \multirow{2}{*}{$\begin{array}{l}\text { RC1 } \\
6.7 \%\end{array}$} & $\min$ & 0.4020 & 0.3194 & 0.8349 & 0.1372 & 0.0248 & 0.0029 & 0.0001 & 0.0000 & 0.1962 \\
\hline & & $\max$ & 0.5220 & 0.5791 & 0.6391 & 0.2741 & 0.0737 & 0.0122 & 0.0009 & 0.0000 & 0.4616 \\
\hline & \multirow{2}{*}{$\begin{array}{c}\text { RC3.2 } \\
11.5 \% \\
\end{array}$} & $\min$ & 0.4620 & 0.4319 & 0.7524 & 0.1985 & 0.0429 & 0.0059 & 0.0003 & 0.0000 & 0.3033 \\
\hline & & $\max$ & 0.6020 & 0.8414 & 0.4491 & 0.3721 & 0.1435 & 0.0321 & 0.0031 & 0.0000 & 0.7682 \\
\hline \multicolumn{4}{|c|}{ LA XEREA } & \multicolumn{7}{|c|}{ Probability of each damage grade } & \multirow[b]{2}{*}{ DSm } \\
\hline & Typology & \multicolumn{2}{|c|}{ VI } & $\mu \mathrm{d}$ & D0 & D1 & D2 & D3 & D4 & D5 & \\
\hline \multirow{8}{*}{$\begin{array}{l}b \\
\stackrel{\Xi}{\bar{n}} \\
\stackrel{\Xi}{\Xi} \\
\stackrel{\Xi}{=}\end{array}$} & \multirow{2}{*}{$\begin{array}{l}\text { M 3.1 } \\
52.8 \% \\
\end{array}$} & $\min$ & 0.6600 & 0.3499 & 0.8132 & 0.1538 & 0.0292 & 0.0036 & 0.0002 & 0.0000 & 0.2238 \\
\hline & & $\max$ & 0.8607 & 0.9149 & 0.4021 & 0.3888 & 0.1648 & 0.0400 & 0.0042 & 0.0001 & 0.8556 \\
\hline & \multirow{2}{*}{$\begin{array}{c}\text { M 3.3 } \\
9.1 \%\end{array}$} & $\min$ & 0.6258 & 0.2940 & 0.8524 & 0.1236 & 0.0214 & 0.0025 & 0.0001 & 0.0000 & 0.1743 \\
\hline & & $\max$ & 0.8318 & 0.8034 & 0.4747 & 0.3615 & 0.1326 & 0.0285 & 0.0026 & 0.0000 & 0.7230 \\
\hline & RC1 & $\min$ & 0.3820 & 0.0817 & 0.9715 & 0.0252 & 0.0030 & 0.0003 & 0.0000 & 0.0000 & 0.0320 \\
\hline & $6.7 \%$ & $\max$ & 0.6220 & 0.2884 & 0.8563 & 0.1206 & 0.0207 & 0.0024 & 0.0001 & 0.0000 & 0.1695 \\
\hline & RC3.2 & $\min$ & 0.4820 & 0.1390 & 0.9452 & 0.0478 & 0.0064 & 0.0006 & 0.0000 & 0.0000 & 0.0624 \\
\hline & $11 \%$ & $\max$ & 0.6220 & 0.2884 & 0.8563 & 0.1206 & 0.0207 & 0.0024 & 0.0001 & 0.0000 & 0.1695 \\
\hline & M 3.1 & $\min$ & 0.6600 & 0.7610 & 0.5041 & 0.3482 & 0.1207 & 0.0247 & 0.0022 & 0.0000 & 0.6727 \\
\hline & $52.8 \%$ & $\max$ & 0.8607 & 1.7413 & 0.0920 & 0.3290 & 0.3461 & 0.1856 & 0.0451 & 0.0021 & 1.7692 \\
\hline & М 3.3 & $\min$ & 0.6258 & 0.6487 & 0.5862 & 0.3055 & 0.0908 & 0.0163 & 0.0013 & 0.0000 & 0.5410 \\
\hline 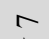 & $9.1 \%$ & $\max$ & 0.8318 & 1.5677 & 0.1291 & 0.3659 & 0.3239 & 0.1491 & 0.0308 & 0.0012 & 1.5902 \\
\hline .2 & RC1 & $\min$ & 0.3820 & 0.1906 & 0.9175 & 0.0711 & 0.0104 & 0.0010 & 0.0000 & 0.0000 & 0.0951 \\
\hline$\overline{0}$ & $6.7 \%$ & $\max$ & 0.6220 & 0.6371 & 0.5949 & 0.3005 & 0.0878 & 0.0156 & 0.0012 & 0.0000 & 0.5277 \\
\hline$\stackrel{O}{\Xi}$ & RC3.2 & $\min$ & 0.4820 & 0.3194 & 0.8349 & 0.1372 & 0.0248 & 0.0029 & 0.0001 & 0.0000 & 0.1962 \\
\hline & $11 \%$ & $\max$ & 0.6220 & 0.6371 & 0.5949 & 0.3005 & 0.0878 & 0.0156 & 0.0012 & 0.0000 & 0.5277 \\
\hline
\end{tabular}

Table 5 Damage Probability Matrices (DPM) for the maximum and minimum values of the Vulnerability Index in each neighbourhood and for each scenario. 


\begin{tabular}{|c|c|c|c|c|c|c|c|c|c|c|c|}
\hline \multicolumn{4}{|c|}{ LA XEREA (continues) } & \multirow[b]{2}{*}{$\mu \mathrm{d}$} & \multicolumn{6}{|c|}{ Probability of each damage grade } & \multirow[b]{2}{*}{ DSm } \\
\hline & Typology & \multicolumn{2}{|c|}{ VI } & & D0 & D1 & D2 & D3 & D4 & D5 & \\
\hline \multirow{8}{*}{ 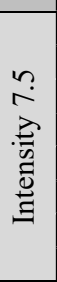 } & \multirow{2}{*}{$\begin{array}{r}\text { M 3.1 } \\
52.8 \% \\
\end{array}$} & $\min$ & 0.6600 & 1.0855 & 0.3062 & 0.4097 & 0.2139 & 0.0621 & 0.0079 & 0.0002 & 1.0563 \\
\hline & & $\max$ & 0.8607 & 2.2609 & 0.0307 & 0.2065 & 0.3511 & 0.2898 & 0.1121 & 0.0097 & 2.2750 \\
\hline & M 3.3 & $\min$ & 0.6258 & 0.9358 & 0.3894 & 0.3927 & 0.1708 & 0.0424 & 0.0046 & 0.0001 & 0.8803 \\
\hline & $9.1 \%$ & $\max$ & 0.8318 & 2.0683 & 0.0469 & 0.2514 & 0.3595 & 0.2537 & 0.0828 & 0.0058 & .0914 \\
\hline & RC1 & $\min$ & 0.3820 & 0.2884 & 0.8563 & 0.1206 & 0.0207 & 0.0024 & 0.0001 & 0.0000 & 1695 \\
\hline & $6.7 \%$ & $\max$ & 0.6220 & 0.9203 & \begin{tabular}{|c|}
0.3988 \\
\end{tabular} & 0.3899 & 0.1663 & 0.0406 & 0.0043 & 0.0001 & 8619 \\
\hline & RC3.2 & $\min$ & 0.4820 & 0.4767 & 0.7181 & 0.2225 & 0.0514 & 0.0075 & 0.0005 & 0.0000 & 3498 \\
\hline & $11 \%$ & $\max$ & 0.6220 & 0.9203 & 0.3988 & 0.3899 & 0.1663 & 0.0406 & 0.0043 & 0.0001 & .8619 \\
\hline EL & CARME & & & & & Proba & lity of e & h dama & grade & & \\
\hline & Typology & & & $\mu \mathrm{d}$ & D0 & D1 & D2 & D3 & D4 & D5 & DSm \\
\hline & M 3.1 & $\min$ & 0.6600 & 0.3499 & 0.8132 & 0.1538 & 0.0292 & 0.0036 & 0.0002 & 0.0000 & 0.2238 \\
\hline & $53.2 \%$ & $\max$ & 0.9081 & 1.1233 & 0.2875 & 0.4111 & 0.2245 & 0.0677 & 0.0090 & 0.0002 & 1.1001 \\
\hline r & M4 & $\min$ & 0.3910 & 0.0857 & 0.9699 & 0.0266 & 0.0032 & 0.0003 & 0.0000 & 0.0000 & 0340 \\
\hline$\stackrel{3}{n}$ & $8.6 \%$ & $\max$ & 0.5310 & 0.1799 & 0.9235 & 0.0660 & 0.0095 & 0.0009 & 0.0000 & 0.0000 & .0879 \\
\hline ల్ & RC1 & $\min$ & 0.3820 & 0.0817 & 0.9715 & 0.0252 & 0.0030 & 0.0003 & .0000 & 0.0000 & .0320 \\
\hline$\Xi$ & $13.8 \%$ & $\max$ & 0.7620 & 0.5791 & 0.6391 & 0.2741 & 0.0737 & 0.0122 & .0009 & 0.0000 & .4616 \\
\hline & RC3.2 & $\min$ & 0.4620 & 0.1251 & 0.9521 & 0.0420 & 0.0055 & 0.0005 & 0000 & 0.0000 & .0544 \\
\hline & $18 \%$ & $\max$ & 0.7820 & 0.6371 & 0.5949 & 0.3005 & 878 & 0.0 & & 0.0 & .5277 \\
\hline & M 3.1 & $\min$ & 0.6600 & 0.7610 & 0.5041 & 0.3482 & 0.1207 & 0.0247 & 0022 & 0.0000 & 6727 \\
\hline & $53.2 \%$ & $\max$ & 0.9081 & 2.0438 & 0.0494 & 0.2573 & 0.3597 & 02 & 795 & 0.0054 & .0678 \\
\hline - & M 4 & $\min$ & 0.3910 & 0.1998 & 22 & 0.0754 & 0.0112 & 0.0 & 00 & 0.0 & 1014 \\
\hline$=$ & $8.6 \%$ & $\max$ & 0.5310 & 0.4089 & 0.7698 & 0.1860 & 0.0388 & 0.0052 & 0.0003 & 0.0000 & 0.2802 \\
\hline อี & RC1 & $\min$ & 0.3820 & 0.1906 & 0.9175 & 0.0711 & 0.0104 & 0.0010 & .0000 & 0.0000 & .0951 \\
\hline$\Xi$ & $13.8 \%$ & $\max$ & 0.7620 & 1.1906 & 64 & 0.4112 & 0.2427 & & & & 773 \\
\hline & RC3.2 & $\min$ & 0.4620 & 0.2884 & 0.8563 & 0.1206 & 0.0207 & 0.00 & 01 & 0.0 & 1695 \\
\hline & $18 \%$ & $\max$ & 0.7820 & 1.2920 & 47 & 0.4058 & 0.2684 & 0.0956 & & 0.0 & 2918 \\
\hline & M 3.1 & $\min$ & 0.6600 & 1.0855 & 62 & 0.4097 & 2139 & 1 & & 0.0 & 0563 \\
\hline & $53.2 \%$ & $\max$ & 0.9081 & 2.5820 & 44 & 0.1398 & 0.3153 & 0.3 & 24 & 0.0 & .5770 \\
\hline$\pi$ & M 4 & $\min$ & 0.3910 & 0.3020 & 0.8470 & 0.1278 & 0.0225 & 0.0026 & 0.0001 & 0.0000 & 0.1811 \\
\hline$\gtrsim$ & $8.6 \%$ & $\max$ & 0.5310 & 0.6046 & 0.6196 & 0.2860 & 0.0798 & & & 0.0 & 4905 \\
\hline $\overrightarrow{\bar{n}}$ & RC1 & $\min$ & 0.3820 & 0.2884 & & 0.1 & & 0.0 & & & 695 \\
\hline$\stackrel{\text { g }}{\Xi}$ & $13.8 \%$ & $\max$ & 0.7620 & 1.6279 & 0.1150 & 0.3538 & 0.3328 & 0.1 & 54 & 0.0 & 6530 \\
\hline & RC3.2 & $\min$ & 0.4620 & 0.4319 & & 0.1985 & 0.0429 & 9 & & 0.0 & 3033 \\
\hline & $18 \%$ & $\max$ & & & & 0.3272 & 0.3469 & 0.1873 & 0.0459 & & 773 \\
\hline EL & PILAR & & & & & Proba & lity of e & dama & grade & & \\
\hline & Typology & & & $\mu \mathrm{d}$ & D0 & D1 & $\mathrm{D} 2$ & D3 & D4 & D5 & DSm \\
\hline & M 3.1 & $\min$ & 0.6600 & 0.3499 & $\begin{array}{l}0.8132 \\
\end{array}$ & 0.1538 & 0.0292 & 0.0036 & 0.0002 & 0.0000 & 0.2238 \\
\hline & $50.5 \%$ & $\max$ & 0.8871 & 1.0272 & 59 & 0.4053 & 73 & 40 & 0.0064 & 0.0001 & 9882 \\
\hline 0 & M4 & $\min$ & 0.3910 & 0.0857 & 0.9699 & 0.0266 & 0.0032 & 0.0003 & 0.0000 & 0.0000 & .0340 \\
\hline 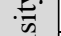 & $9 \%$ & $\max$ & 0.5710 & 0.2217 & 0.8992 & 0.0861 & 0.0133 & 0.0014 & 0.0001 & 0.0000 & 0.1170 \\
\hline อ & RC1 & $\min$ & 0.3820 & 0.0817 & 0.9715 & 0.0252 & 0.0030 & 0.0003 & 0.0000 & 0.0000 & 0.0320 \\
\hline$\Xi$ & $13.3 \%$ & $\max$ & 0.7420 & 0.5257 & & 0.2 & & & 0. & & 024 \\
\hline & RC3.2 & $\min$ & 4420 & 0.1125 & 80 & 0.0369 & 0.0047 & 0.0 & 0.0 & 0.0 & 0476 \\
\hline & $20.4 \%$ & $\max$ & 0.7820 & 0.6371 & 49 & 0.3 & 0.0878 & 0 & 0.0012 & 0.0000 & 5277 \\
\hline & M 3.1 & $\min$ & & 510 & & 0.3482 & 207 & 0247 & 0.0022 & 0.0000 & 6727 \\
\hline & $50.5 \%$ & $\max$ & 0.8871 & 1.9077 & 0.0657 & 0.2900 & 0.3575 & 0.2208 & 0.0625 & 0.0036 & 1.9352 \\
\hline & M 4 & $\min$ & 0.3910 & 0.1998 & 0.9122 & 0.0754 & 0.0112 & 0.0011 & 0.0000 & 0.0000 & 0.1014 \\
\hline$\frac{3}{\infty}$ & $9 \%$ & $\max$ & 0.5710 & 0.4983 & 0.7015 & 0.2338 & 0.0558 & 0.0084 & 0.0005 & 0.0000 & .3726 \\
\hline है & RC1 & $\min$ & 0.3820 & 0.1906 & 75 & 0.0711 & 0.0104 & 0.0010 & 0.0 & 0.0 & 0.0951 \\
\hline$\Xi$ & $13.3 \%$ & $\max$ & 0.7420 & 1.0948 & 15 & 0.4101 & 0.2165 & 0.0 & 0.0 & 0.0 & 0671 \\
\hline & RC3.2 & $\min$ & 4420 & 0.2602 & 49 & 0.1 & 74 & 0.0019 & 0.0001 & 0.0000 & 465 \\
\hline & $20.4 \%$ & $\max$ & 0.7820 & 1.2920 & & 0.4058 & 0.2684 & 0.0956 & 0.0151 & 0.0004 & .2918 \\
\hline & M 3.1 & $\min$ & 0.6600 & 1.0855 & 0.3062 & $\mathbf{0 . 4 0 9 7}$ & 0.2139 & 0.0621 & 0.0079 & 0.0002 & 1.0563 \\
\hline & $50.5 \%$ & $\max$ & 0.8871 & 2.4397 & 0.0204 & 0.1679 & 0.3342 & 0.3184 & 0.1439 & 0.0152 & 2.4434 \\
\hline$r$ & M 4 & $\min$ & 0.3910 & 0.3020 & \begin{tabular}{|c|}
0.8470 \\
\end{tabular} & 0.1278 & 0.0225 & 0.0026 & 0.0001 & 0.0000 & 0.1811 \\
\hline 党 & $9 \%$ & $\max$ & 0.5710 & 0.7300 & .5262 & 0.3375 & 0.1122 & 0.0222 & 0.0019 & 0.0000 & 0.6361 \\
\hline 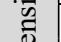 & RC1 & $\min$ & 0.3820 & 0.2884 & 8563 & 0.1206 & 0.0207 & 0.0024 & 0.0001 & 0.0000 & 1695 \\
\hline$\stackrel{0}{=}$ & $13.3 \%$ & $\max$ & 0.7420 & 1.5109 & 438 & 0.3764 & 0.3144 & 0.1375 & 0.0269 & 0.0010 & 1.5302 \\
\hline & RC3.2 & $\min$ & 0.4420 & 0.3909 & 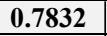 & 0.1762 & 0.0357 & 0.0047 & 0.0003 & 0.0000 & 0.2626 \\
\hline & $20.4 \%$ & $\max$ & 0.7820 & 1.7494 & .0906 & 0.3272 & 0.3469 & 0.1873 & 0.0459 & 0.0022 & 1.7773 \\
\hline EL & $\mathbf{R C}$ & & & & & Prob & ty of $c$ & h dama & grade & & \\
\hline & Typology & & VI & d & $\mathrm{D}$ & D1 & $\mathrm{D} ?$ & D3 & $\mathrm{D} 4$ & D5 & $\mathrm{DSm}$ \\
\hline & M 3.1 & $\min$ & 0.6600 & 0.3499 & & 0.1538 & 0.0292 & 0.0036 & 0.0002 & 0.0000 & 0.2238 \\
\hline & $64.9 \%$ & $\max$ & 0.9290 & 1.2254 & 0.2414 & 0.4101 & 0.2517 & 0.0841 & 0.0124 & 0.0003 & 1.2169 \\
\hline & M 4 & $\min$ & 0.3910 & 0.0857 & 0.9699 & 0.0266 & 0.0032 & 0.0003 & 0.0000 & 0.0000 & 0.0340 \\
\hline$\stackrel{s}{n}$ & $9 \%$ & $\max$ & 0.6110 & 0.2726 & 0.8668 & 0.1122 & 0.0188 & 0.0021 & 0.0001 & 0.0000 & 0.1565 \\
\hline ల్ & RC1 & $\min$ & 0.3820 & 0.0817 & 0.9715 & 0.0252 & 0.0030 & 0.0003 & 0.0000 & 0.0000 & 0.0320 \\
\hline 芭 & $9.7 \%$ & $\max$ & 0.7220 & 0.4767 & 0.7181 & 0.2225 & 0.0514 & 0.0075 & 0.0005 & 0.0000 & 0.3498 \\
\hline & RC3.2 & $\min$ & 0.4420 & & & 0.0369 & 0.0047 & 0.0004 & 0.0000 & 0.0000 & 0.0476 \\
\hline & $7.8 \%$ & $\max$ & 0.8020 & 0.7000 & 0.5480 & 0.3263 & 0.1041 & 0.0199 & 0.0016 & 0.0000 & 0.6009 \\
\hline
\end{tabular}




\begin{tabular}{|c|c|c|c|c|c|c|c|c|c|c|c|}
\hline \multicolumn{4}{|c|}{ EL MERCAT (continues) } & \multirow[b]{2}{*}{$\mu \mathrm{d}$} & \multicolumn{6}{|c|}{ Probability of each damage grade } & \multirow{3}{*}{$\begin{array}{l}\mathrm{DSm} \\
0.6727\end{array}$} \\
\hline & Typology & \multicolumn{2}{|c|}{ VI } & & D0 & D1 & D2 & D3 & D4 & D5 & \\
\hline \multirow{8}{*}{ 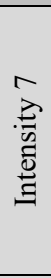 } & \multirow{2}{*}{$\begin{array}{r}\text { M 3.1 } \\
64.9 \% \\
\end{array}$} & $\min$ & 0.6600 & 0.7610 & 0.5041 & 0.3482 & 0.1207 & 0.0247 & 0.0022 & 0.0000 & \\
\hline & & $\max$ & 0.9290 & 2.1823 & 0.0366 & 0.2245 & 0.3559 & 0.2757 & 0.0995 & 0.0079 & 2.2005 \\
\hline & \multirow{2}{*}{$\begin{array}{l}\text { M } 4 \\
9 \%\end{array}$} & $\min$ & 0.3910 & 0.1998 & 0.9122 & 0.0754 & 0.0112 & 0.0011 & 0.0000 & 0.0000 & 1014 \\
\hline & & $\max$ & 0.6110 & 0.6046 & 0.6196 & 0.2860 & 0.0798 & 0.0136 & 0.0010 & 0.0000 & 0.4905 \\
\hline & \multirow{2}{*}{$\begin{array}{l}\text { RC1 } \\
9.7 \% \\
\end{array}$} & $\min$ & 0.3820 & 0.1906 & 0.9175 & 0.0711 & 0.0104 & 0.0010 & 0.0000 & 0.0000 & 0.0951 \\
\hline & & $\max$ & 0.7220 & 1.0047 & 0.3493 & 0.4028 & 0.1908 & 0.0510 & 0.0059 & 0.0001 & 0.9617 \\
\hline & \multirow{2}{*}{$\begin{array}{c}\text { RC3.2 } \\
7.8 \% \\
\end{array}$} & $\min$ & 0.4420 & 0.2602 & 0.8749 & 0.1058 & 0.0174 & 0.0019 & 0.0001 & 0.0000 & 0.1465 \\
\hline & & $\max$ & 0.8020 & 1.3988 & 0.1771 & 0.3940 & 0.2926 & 0.1154 & 0.0202 & 0.0006 & 1.4096 \\
\hline \multirow{8}{*}{ 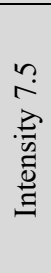 } & \multirow{2}{*}{$\begin{array}{l}\text { M 3.1 } \\
64.9 \%\end{array}$} & $\min$ & 0.6600 & 1.0855 & 0.3062 & 0.4097 & 0.2139 & & 0.0079 & .0002 & 1.0563 \\
\hline & & $\max$ & 0.9 & 2.7235 & 0.0 & 0.1147 & 925 & & 0.2030 & .0297 & 7102 \\
\hline & \multirow{2}{*}{$\begin{array}{l}\text { M 4 } \\
9 \% \\
\end{array}$} & $\min$ & 0.3910 & 0.3020 & 0.8470 & 0.1278 & 225 & .0026 & 0.0001 & 0000 & 1811 \\
\hline & & $\max$ & 0.6110 & 0.8762 & 0.4265 & 0.3806 & 535 & 7 & 0.0036 & 0001 & 8096 \\
\hline & \multirow{2}{*}{$\begin{array}{l}\text { RC1 } \\
9.7 \%\end{array}$} & $\min$ & 0.3820 & 84 & 0.8 & 0.1206 & 0.0207 & & 0.0001 & .0000 & 1695 \\
\hline & & $\max$ & 0.7220 & 1.3988 & 0.1771 & 0.3940 & 0.2926 & 0.1 & 0.0202 & .0006 & 1.4096 \\
\hline & \multirow{2}{*}{$\begin{array}{c}\text { RC3.2 } \\
7.8 \% \\
\end{array}$} & $\min$ & 0.4420 & 0.3909 & 0.7832 & 0.1762 & 0.0357 & 0.0047 & 0.0003 & 0.0000 & 0.2626 \\
\hline & & $\max$ & 0.8 & 1.8749 & & 0.2978 & 0.3560 & 0.2 & 0.0588 & 033 & 1.9029 \\
\hline \multicolumn{4}{|c|}{ SANT FRANCESC } & & \multicolumn{6}{|c|}{ Probability of each damage grade } & \multirow[b]{2}{*}{$\mathrm{DSm}$} \\
\hline & Typology & & 1 & $\mu \mathrm{d}$ & D0 & D1 & $\mathrm{D} 2$ & $\mathrm{D} 3$ & $\mathrm{D} 4$ & D5 & \\
\hline & M 3.1 & $\min$ & 0.6600 & 0.3499 & 0.8132 & 0.1538 & 0.0292 & 0.0036 & 0.0002 & 0.0000 & 0.2238 \\
\hline & $27.4 \%$ & $\max$ & & 1.1233 & & & & & 0.0090 & .0002 & 1.1001 \\
\hline & M 3.3 & $\min$ & & & & & & & 0.0000 & & 340 \\
\hline & $10.6 \%$ & $\max$ & 0.5310 & 0.1799 & 0.9 & 0.0 & 95 & 0.0 & 0.0000 & 000 & 0879 \\
\hline 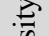 & S 3 & $\min$ & 0.3820 & & & & & & 0.0000 & 0000 & 0320 \\
\hline 0 & $15 \%$ & $\max$ & 0. & & & & & & 0.0009 & 0000 & 4616 \\
\hline$\Xi$ & RC1 & $\min$ & 0.4620 & 0.1251 & 0.9 & 0.0420 & 0.0055 & 00 & 0.0000 & .0000 & 0.0544 \\
\hline & $25.6 \%$ & $\max$ & 0.7820 & 0.6371 & 0.5949 & 0.3005 & 0.0878 & 0 & 0.0012 & .0000 & 0.5277 \\
\hline & RC3.2 & $\min$ & & & & & & & 0.0002 & 0000 & 2238 \\
\hline & $12.4 \%$ & $\max$ & & & & & & & 0.0 & & 7661 \\
\hline & M 3.1 & $\min$ & 0.6600 & 0.7 & 0.5 & & 07 & $y$ & 0.0022 & 0000 & 0.6727 \\
\hline & $27.4 \%$ & $\max$ & 5 & & & & & & 0.0351 & 0014 & 1.6502 \\
\hline & M 3.3 & $\min$ & 0.6240 & 0.6432 & 0.5903 & 0.3031 & 0.0894 & 60 & 0.0012 & .0000 & 0.5347 \\
\hline & $10.6 \%$ & $\max$ & 0.8311 & 1.5636 & 0.1301 & 0.3667 & 0.3233 & 0.1483 & 0.0305 & 0.0012 & 1.5859 \\
\hline$\stackrel{\vec{c}}{\mathrm{~s}}$ & S 3 & $\min$ & 0.3820 & 0.1906 & 0.9175 & 0.0711 & 0.0104 & 0.0010 & 0.0000 & 0.0000 & 0.0951 \\
\hline J & $15 \%$ & $\max$ & 0.7020 & 0.9203 & & & & & 0.0043 & 01 & 0.8619 \\
\hline$\Xi$ & RC1 & $\min$ & 0.4420 & 0.2602 & & & & & 0.0001 & 00 & 0.1465 \\
\hline & $25.6^{\circ}$ & $\max$ & 07 & U & & 0. & 84 & 6 & 0.0151 & 004 & 1.2918 \\
\hline & RC3.2 & $\min$ & 0 . & & & 0.0939 & 48 & 6 & 0.0001 & .0000 & 0.1286 \\
\hline & $12.4 \%$ & $\max$ & 0.7640 & 1.2005 & 0.2521 & 0.4110 & 0.2453 & 0.0799 & 0.0115 & 0.0003 & 1.1886 \\
\hline & M 3.1 & $\min$ & 0.6600 & 1.0855 & 0.3062 & $\mathbf{0 . 4 0 9 7}$ & 0.2139 & 0.0621 & 0.0079 & .0002 & 1.0563 \\
\hline & $27.4 \%$ & $\max$ & 0.8415 & 2.1327 & 0.0408 & 0.2361 & 0.3579 & 0.2663 & 0.0920 & .0069 & 2.1533 \\
\hline & M 3.3 & $\min$ & 0.6240 & 0.9285 & & & 687 & 116 & 0.0044 & 0001 & 0.8716 \\
\hline$\pi$ & $10.6 \%$ & $\max$ & 0.8311 & 2.0637 & & & 595 & & 0.0822 & 0057 & 2.0870 \\
\hline 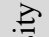 & & $\min$ & 0.3820 & 0.28 & & & 0.0207 & .0024 & 0.0001 & .0000 & 0.1695 \\
\hline$\overline{\breve{a}}$ & $15 \%$ & $\max$ & 0.7020 & 1.2920 & & 0.4058 & 0.2684 & 0.0956 & 0.0151 & 0.0004 & 1.2918 \\
\hline$\stackrel{0}{=}$ & RC1 & $\min$ & 0.4420 & 0.3909 & 0.7 & 0.1762 & 0.0357 & 0.0047 & 0.0003 & 0.0000 & 0.2626 \\
\hline & $25.6 \%$ & $\max$ & 0.7820 & 1.7494 & 0.0906 & 0.3272 & 0.3469 & 0.1873 & 0.0459 & 0.0022 & 1.7773 \\
\hline & RC3.2 & $\min$ & 0.4240 & 0.3571 & 0.8081 & 0.1577 & 0.0303 & 0.0038 & 0.0002 & 0.0000 & 0.2304 \\
\hline & $12.4 \%$ & $\max$ & 0.7640 & 1.6398 & 0.1123 & 0.3513 & 0.3344 & 0.1641 & 0.0363 & 0.0015 & 1.6653 \\
\hline
\end{tabular}

DAMAGE PROBABHITY MATRIX . INT

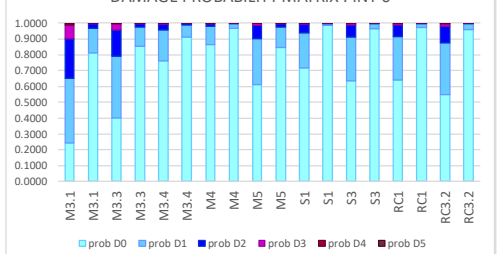

Fig. 22 Damage Probability Matrices for each seismic scenario
DAMAGE PROBABHTYMATRIX INT7

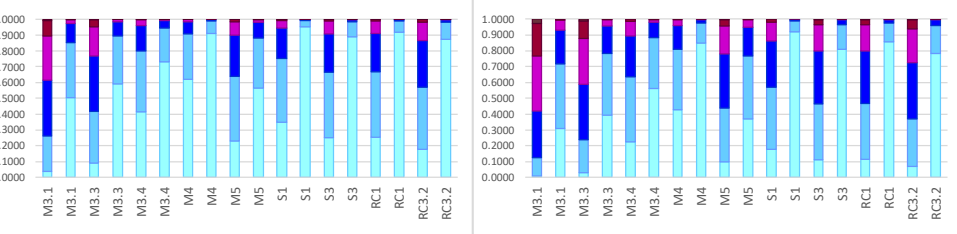

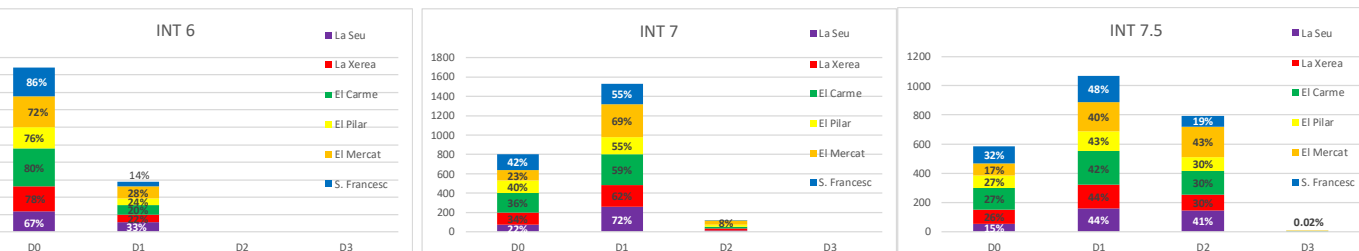

Fig. 23 Probable distribution of damage grades in each neighbourhood, for each seismic intensity 


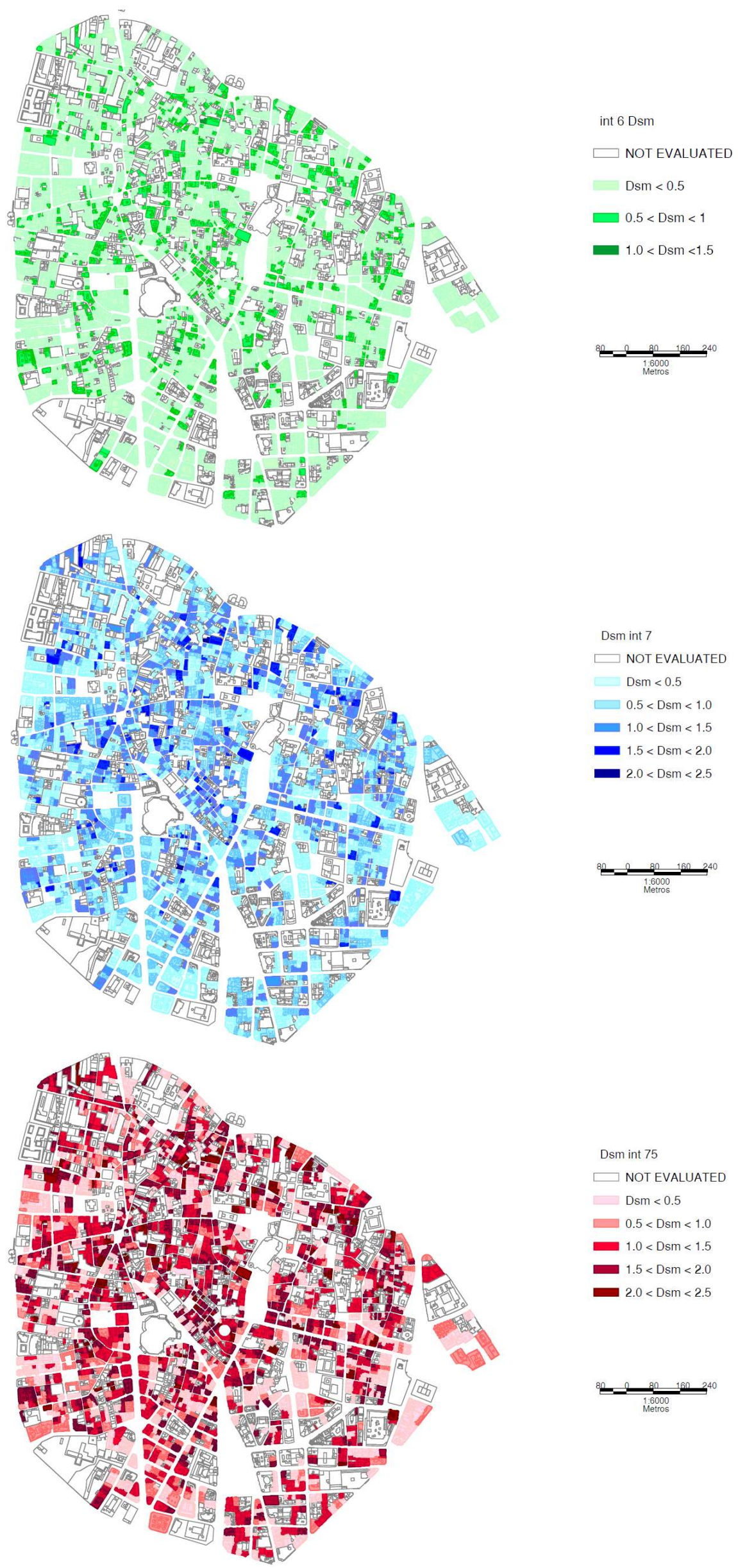

Fig. 24 Mean damage index distribution for intensity 6, intensity 7 and intensity 7.5 
To facilitate damage appraisal, the estimated mean damage index distribution in the building stock under analysis has been represented for the three scenarios in Figure 24, using a GIS tool. The more vulnerable buildings are therefore identified.

As the results confirm, not being Valencia a zone of high seismicity, although the majority of the buildings are classified as class B, only slight (D1) or moderate (D2) damage is expected for the residential building stock in Ciutat Vella, except from the probabilistic scenario with intensity 7.5 in which substantial to heavy damage (D3) may occur (with a frequency of $0.1 \%$ for D5, $2 \%$ for D4 and 9\% for D3).

The estimated probable damage ranges from 0.03 to 1.22 (intensity 6), 0.09 to 2.2 (intensity 7 ) and 0.17 to 2.71 (intensity 7.5). This corresponds with the data from historic reports and damage statistics.

Even the important number of buildings expected to undergo slight damage $(23 \%$ of the residential buildings for intensity $6,62 \%$ for intensity 7 and $43 \%$ for intensity 7.5 ), the probability exists for some buildings to exhibit moderate damage (5\% for intensity 7 and $32 \%$ for intensity 7.5 ) and also substantial to heavy damage $(8 \%$ for intensity 7.5$)$. The number of buildings with no damage will be $76 \%, 32 \%$ and $23 \%$ respectively for each scenario.

Comparing the damage scenarios with the Vulnerability index Map (figure 19) it stands out that the most significant damages are related with the most vulnerable buildings corresponding to typology M 3.1 located in El Mercat neighbourhood, while RC and Steel buildings will suffer mostly slight damage. It is also worthwhile pointing out that the seismic performance of retrofitted buildings (typologies M4 and M5) is adequate, with an expected slight damage level.

\section{LOSS ESTIMATION}

Physical damage assessment is only the first step in the estimation of seismic loss. Seismic risk analysis is completed with the evaluation of the direct social and economic losses associated to the district of Ciutat Vella, for each seismic scenario. Social losses are expressed in terms of potential casualties and number of homeless (due to uninhabitable buildings) whereas economic losses are expressed in terms of repair and replacement costs of the damaged structures in square metres corresponding to the equivalent built area destroyed by the earthquake and in millions of euros.

Finally, the volume of expected debris has also been estimated, being of special importance in old city centres with an irregular urban layout of medieval narrow streets, as Ciutat Vella, for its direct influence on the accessibility of rescue teams.

\subsection{DIRECT SOCIAL LOSSES: CASUALTIES AND HOMELESS}

A big percentage of the fatalities and nearly all the injuries attributed to earthquakes are caused by collapse of buildings. The mortality and morbidity rates depend on a series of factors such as the different types of buildings, the number of buildings damaged, the size of the earthquake and the buildings' occupancy when the earthquake occurs, among others.

The model selected for human loss estimation in this study (Coburn and Spence 2002) is based on damage data from past earthquakes and has been used in the seismic risk assessment of districts such as L'Eixample in Valencia (Guardiola-Víllora and Basset-Salom 2015) or Ciutat Vella in Barcelona (Lantada et al. 2018), in cities such as Granada (Feriche 2012) or Barcelona (Lantada et al. 2008, Lantada et al. 2010 ) or at a national level in countries such as Portugal (Sousa and Campos Costa 2016) or Turkey (Müge ün 2011). According to this model, the total number of possible casualties Ks (eq.8), due to collapsed buildings can be expressed as:

$\mathrm{Ks}=\mathrm{C} \times[\mathrm{M} 1 \times \mathrm{M} 2 \times \mathrm{M} 3 \times(\mathrm{M} 4+\mathrm{M} 5 \times(1-\mathrm{M} 4))]$

being $\mathrm{C}$ the total number of collapsed buildings; M1 the occupancy rate (number of inhabitants per building); M2 the occupancy at time of earthquake; M3 the percentage of occupants trapped by collapse; M4 the injury distribution at collapse and M5 the mortality post-collapse.

$\mathrm{C}$ is obtained by summing the number of buildings of each typology multiplied by the corresponding probability of heavy and destruction damage grade (D4+D5).

The occupancy rate (number of inhabitants per building), M1, is obtained from the number of inhabitants in each neighbourhood of Ciutat Vella (information provided by 2018 demographic census of Valencia, 
Instituto Nacional de Estadística 2018) and their built area (cadastral database). The built area includes all residential buildings with good or medium maintenance level and $30 \%$ of the buildings with bad maintenance level (assuming the rest being uninhabited).

The factor M2, a percentage of M1, estimates the occupancy at time of earthquake according to daily population dynamics. The number of people exposed to an earthquake depends on the time of the day that it occurs (Spence and So, 2011) assuming that, during early daytime and night hours, most of the population is at home, whereas during daytime some of the population is outdoors.

The value of M2 is taken from the occupancy model proposed by Coburn and Spence (2002) as a function of time for urban residential buildings (curve 2 in figure 25). Two different scenarios have been considered, corresponding to earthquakes striking at two different times of the day, namely at $12.00 \mathrm{~h}$ and at $24.00 \mathrm{~h}$, with minimum (42\%) and maximum (80\%) occupancy, respectively.

The occupancy at $12.00 \mathrm{~h}$ has been increased, for each neighbourhood, according to the percentage of the population over 80 years (from $4.9 \%$ in El Pilar to $8.5 \%$ in Sant Francesc), considering that people of this age stay indoors all day long.

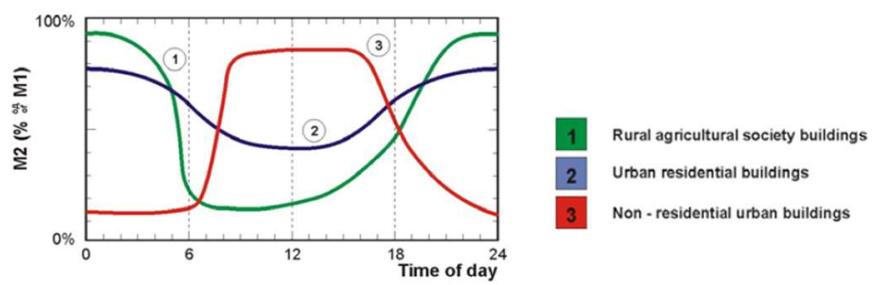

Fig. 25 M2 Occupancy Model. (Coburn and Spence 2002)

The percentage of occupants trapped by building collapse during the earthquake, factor M3, is difficult to predict accurately, because it depends not only on the number of stories of the building or on its ductility but also on the people behaviour at the time of earthquake. The adopted values in this study (Coburn and Spence 2002) for masonry buildings are 5\% and 20\%, respectively, for the probabilistic scenarios of intensity 6 and 7.5, and 5\% for the deterministic scenario (intensity 7). In the case of reinforced concrete and steel buildings, the adopted value is $50 \%$, regardless of the seismic scenario

Factor M4 estimates the injury distribution at the time of collapse, obtained as a percentage of the trapped occupants. A four-stage injury distribution (slight injuries, moderate injuries requiring hospitalization, serious or life-threatening injuries and fatalities) has been proposed depending on the building typology (Coburn and Spence 2002). The values assigned to M4 for masonry buildings are 20\%, $30 \%, 30 \%$ and $20 \%$ respectively, whereas for steel and RC buildings the adopted values are $10 \%, 40 \%$, $10 \%$ and $40 \%$.

The mortality post-collapse (additional mortality of trapped people in collapsed buildings), M5, depends on time, injury level, building structural typology and effectiveness of the emergency rescue activities. Being a community capable of organizing rescue activities, in a district not easily accessible with narrow streets, the adopted values are $60 \%$ for masonry typologies and $90 \%$ for concrete and steel typologies.

The results of the estimation of casualties, injured people distribution and the potential deaths are represented (in absolute value) in figures 26 and 27, respectively, for the three considered scenarios (intensity 6,7 and 7.5 ) at both night time (24h) and day time (12h). Figure 28 shows, by neighbourhood, the distribution of the potential deaths.

In the event of an earthquake of 7.5 intensity during night time, the number of deaths will be 76 , that is 2.79 per thousand $(0.279 \%$ ) of the population in Ciutat Vella (27259 inhabitants), being El Mercat and El Pilar the neighbourhoods with the higher percentage of victims $(0.36 \%$ and $0.37 \%$ of their population $)$ and La Xerea the neighbourhood with the lower percentage $(0.17 \%)$.

The number of homeless people due to the loss of habitability of the buildings is computed from the number of uninhabitable buildings and the occupation ratio thereof (HAZUS 1999).

Considering that buildings expected to undergo damages degrees 4 (very heavy) and 5 (destruction) as well as $90 \%$ of those that will experience damage 3 (substantial to heavy) to be in uninhabitable conditions (Vacareanu et al 2004; Feriche 2012), the number of possible homeless after occurrence of an earthquake of intensities 6, 7 and 7.5 has been evaluated for each neighbourhood (Figure 29) In the event of an earthquake of intensity 6,7 or 7.5 , the expected homeless in the district will be $5 \%$ oo, $37 \%$ and $83 \%$ of the inhabitants in Ciutat Vella, respectively, which represents 156, 1018 or 2262 people. 


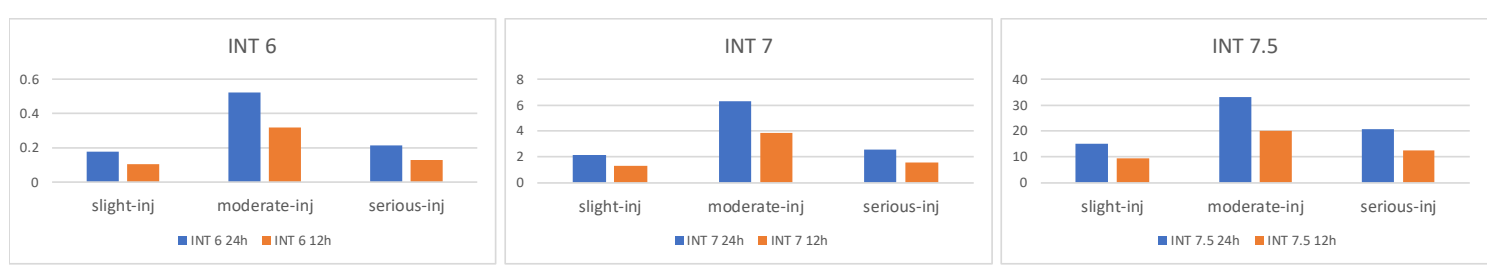

Fig. 26 injured people distribution for each scenario at night time (24h) and day time (12h)

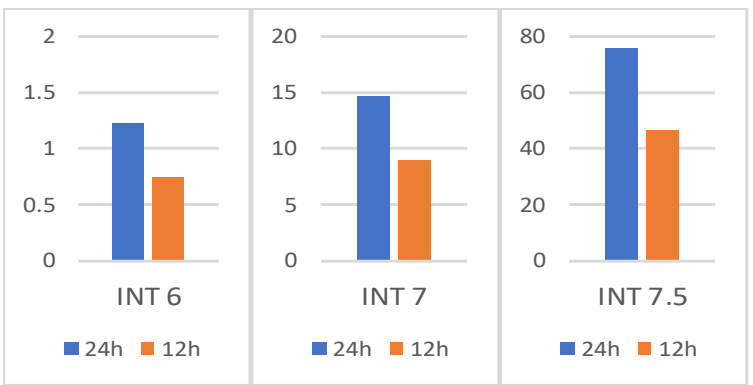

Fig. 27 Potential deaths for each scenario at night time (24h) and day time (12h)

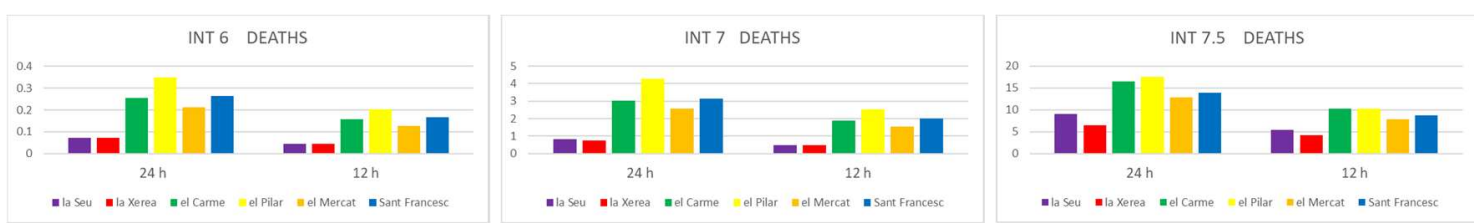

Fig. 28 Potential deaths for each scenario at night time (24h) and day time (12h) in each neighbourhood

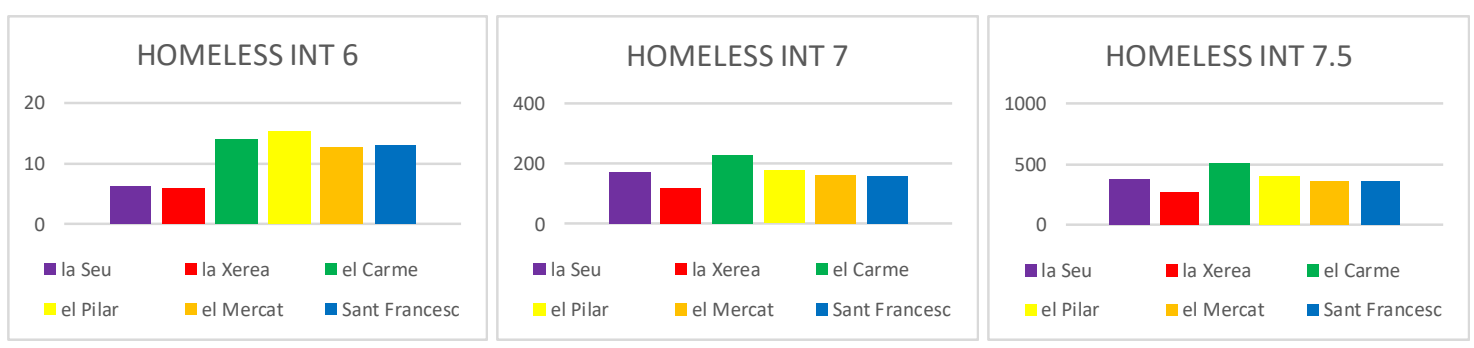

Fig. 29 Homeless people for each seismic scenario

\subsection{DIRECT ECONOMIC LOSSES}

The direct economic losses due to structural or non-structural building damage depend on the probability of occurrence of each damage state and the repair/replacement costs.

According to HAZUS-MH MR3 Technical Manual (FEMA-NIBS 2003), for a given damage state, the building repair/replacement costs are calculated by multiplying the floor area of each building typology (building area in $\mathrm{m}^{2}$ ), the probability of the building typology being in the given damage state (obtained from the corresponding Damage Probability Matrix), and the repair/replacement costs of the building typology per square meter, summed over all building typologies.

A loss ratio of $2 \%, 10 \%$ and $50 \%$ of the building replacement cost is assumed for damage states D1, D2 and D3, respectively; $100 \%$ for D4 and D5.

The unit replacement cost $\left(€ / \mathrm{m}^{2}\right)$ of the buildings has been obtained, according to the current costs in the region, from the "Instituto Valenciano de la Edificación" (2018) considering the characteristics and the average quality of the residential buildings in each neighbourhood (as defined by the City Council database). The adopted values are 700.62 euros $/ \mathrm{m}^{2}$ in Carme, Pilar, Mercat and Seu and 840.75 euros $/ \mathrm{m}^{2}$ in Sant Francesc and Xerea.

For each seismic scenario, the direct economic losses for each neighbourhood and type of structure has been obtained in terms of the equivalent built area destroyed by the earthquake in $\mathrm{m}^{2}$ and in millions of euros. The equivalent built area destroyed is shown, for each seismic scenario, by neighbourhood, by age of the buildings and by building typology in figure 30, figure 31 and figure 32, respectively. 


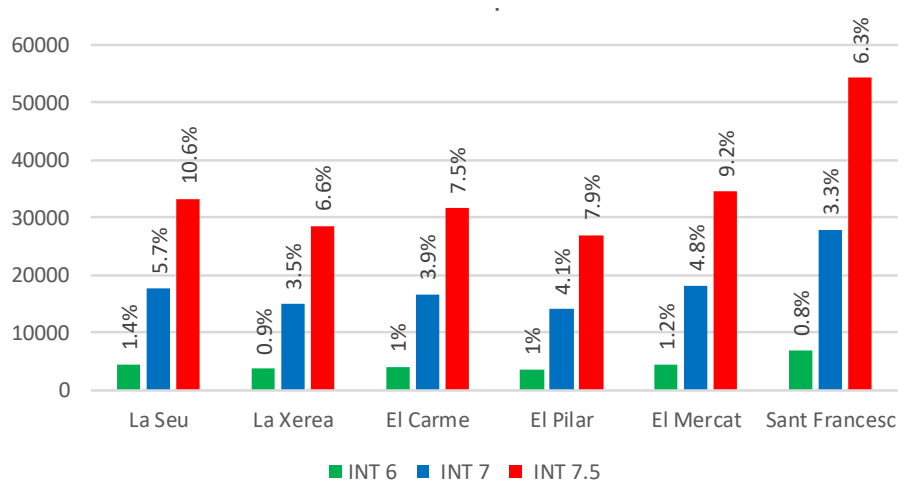

Fig. 30 Destroyed built area $\left(\right.$ in $\left.\mathrm{m}^{2}\right)$ and percentage with respect to the total built area in each neighbourhood

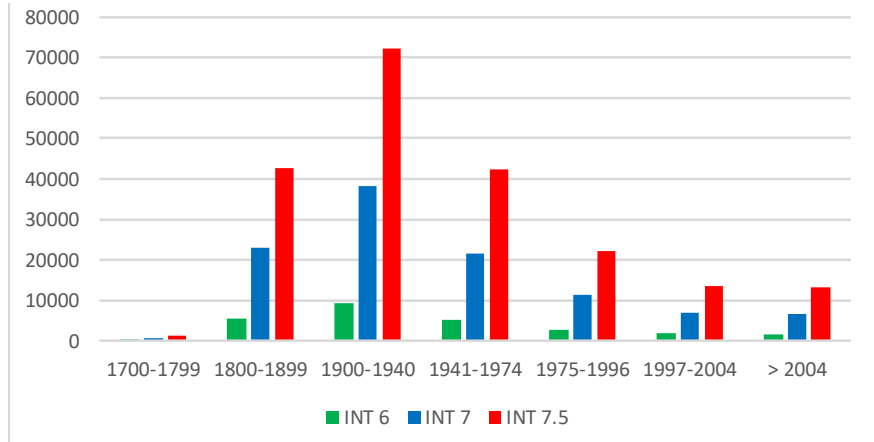

Fig. 31 Destroyed built area $\left(\right.$ in $^{2}$ ) according to the age of the buildings

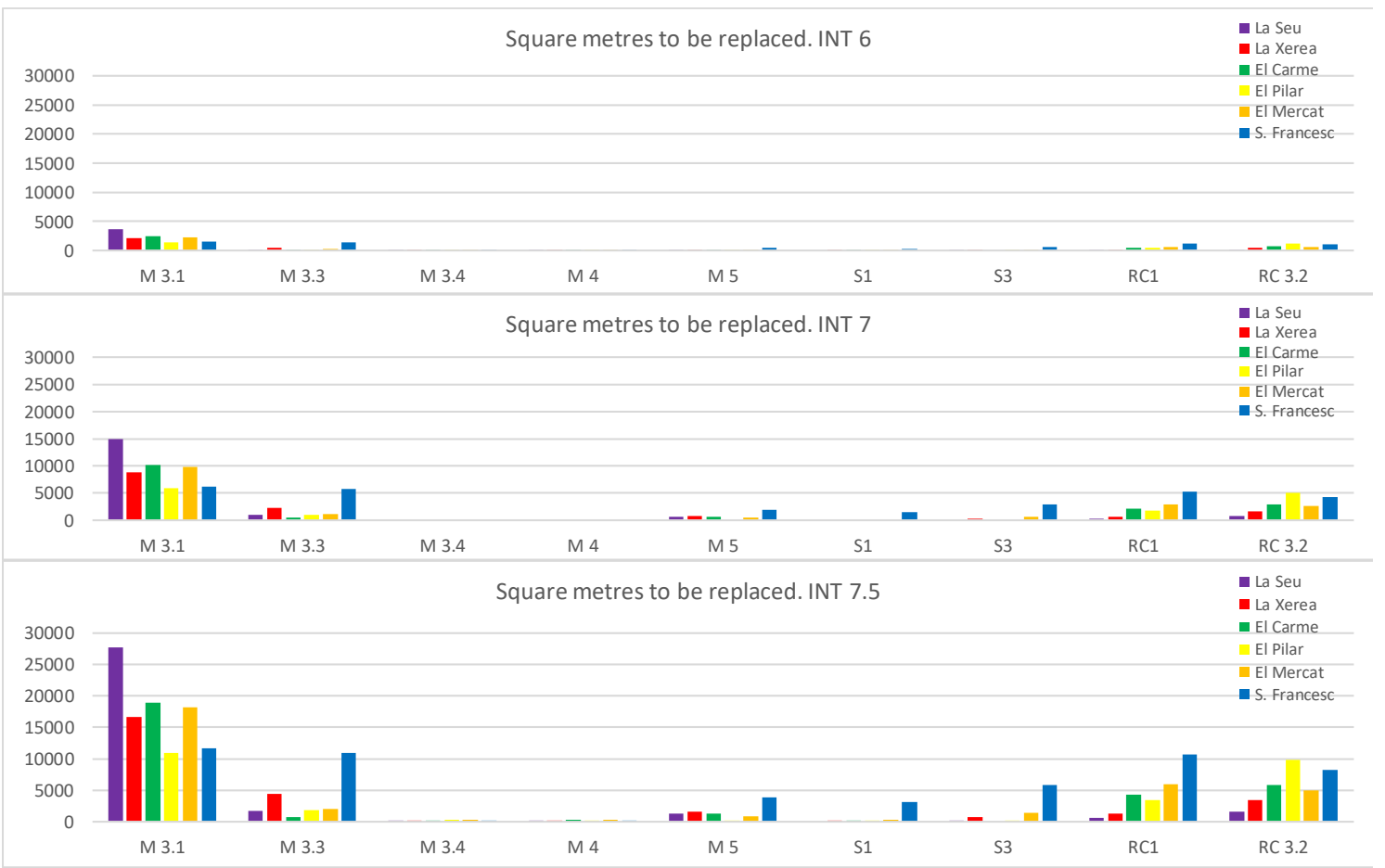

Fig. 32 Destroyed built area $\left(\right.$ in $\left.\mathrm{m}^{2}\right)$ per typology in each neighbourhood

Based on the observation of these diagrams, it should be highlighted that in the event of an earthquake of intensity 7.5, approximately $209190 \mathrm{~m}^{2}$ ( $8 \%$ of the total built residential area in Ciutat Vella) will be destroyed, from which $54272 \mathrm{~m}^{2}, 34637 \mathrm{~m}^{2}, 33145 \mathrm{~m}^{2}$ and $31616 \mathrm{~m}^{2}$ correspond to San Francesc, Mercat, La Seu and El Carme, being La Xerea and El Pilar the less affected neighbourhoods (28565 $\mathrm{m}^{2}$ and 26955 $\mathrm{m}^{2}$ respectively). 
Moreover, for this seismic scenario, $21 \%$ of the expected destroyed built area corresponds to the period $1800-1899\left(42806 \mathrm{~m}^{2}\right), 35 \%$ to the period $1900-1940\left(72220 \mathrm{~m}^{2}\right)$, and $20 \%$ to the period $1940-1974(42535$ $\mathrm{m}^{2}$ ), being M.3.1 the most damaged building typology (49.7\% of the destroyed built area).

Although these numbers are lower for the seismic scenarios of intensities 6 and 7, they should certainly not be neglected. It is further important to stress that about $18400 \mathrm{~m}^{2}$ (intensity 6), $75250 \mathrm{~m}^{2}$ (intensity 7) and $142500 \mathrm{~m}^{2}$ (intensity 7.5) of the destroyed equivalent area, correspond to residential buildings included in the Catalogue of Listed Buildings of the Special Protection Plan of Ciutat Vella (Ayuntamiento de Valencia, 2018). Therefore, the value of these buildings (historical masonry structures) is not limited to the replacement cost, their loss representing much more than the purely material damage.

The cost in millions of euros is shown in figure 33 for each neighbourhood and seismic scenario. The estimated cost for Ciutat Vella District will range from 20 million euros for an earthquake of intensity 6 to 158 million euros for an earthquake of intensity 7.5.

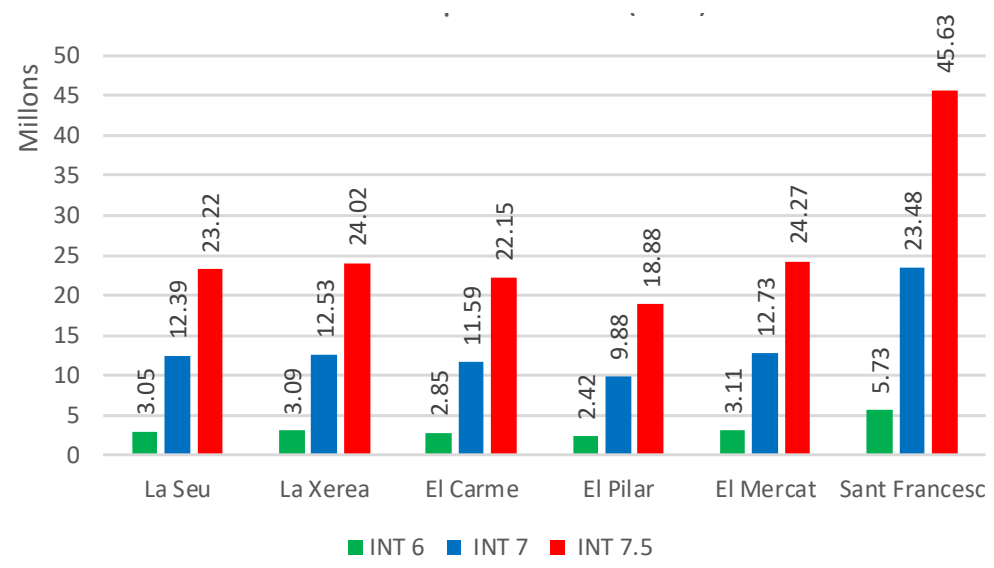

Fig. 33 Cost in million euros for each scenario and neighbourhood

\subsection{DEBRIS GENERATED}

The volume of expected debris generated in the event of an earthquake, must be taken into account, especially in a district as Ciutat Vella with an irregular urban layout consisting of a majority of narrow streets from the Islamic and medieval city.

The debris generated in the different scenarios have been estimated by means of an empirical approach (FEMA/NIBS 2000) which is based on observations of damage occurred in past earthquakes. The model considers two different types of debris according to their size namely (a) small debris which can be easily moved with machinery such as brick, wood, glass and building contents and (b) debris that falls in large pieces which require to be broken into smaller pieces to be hauled away, such as steel members or reinforced concrete elements.

The recommended values for unit weights of structural elements as building debris (tons $/ \mathrm{m}^{2}$ of built area) according to the building typology and the debris fraction of each debris type (\% of unit weight) generated from damaged structural elements for each building typology in each damage state (D1 to D5) have been taken from Hazus99 (FEMA-NIBS 2000).

Considering that a building typology can produce debris from both types, the expected debris fraction, $\operatorname{EDF}(\mathrm{i}, \mathrm{j})$ for debris type $\mathrm{i}$ generated by a building typology $\mathrm{j}$ undergoing a damage state $\mathrm{k}$ (D1 to D5) is obtained (equation $\mathrm{xx}$ ) by multiplying the probability of damage state $\mathrm{k}$ to occur $\mathrm{P}(\mathrm{k}, \mathrm{j})$ and the corresponding debris fraction (of debris type i for damage state $k$ and building typology j), DF (i,k,j), as :

$$
\operatorname{EDF}(\mathrm{i}, \mathrm{j})=\sum_{\mathrm{K}=1}^{5} \mathrm{P}(\mathrm{k}, \mathrm{j}) * \mathrm{DF}(\mathrm{i}, \mathrm{k}, \mathrm{j})
$$

Therefore, the total weight (in tons) of each debris type $\mathrm{i}$ is obtained by summing for each building typology the expected debris fraction $\operatorname{EDF}(\mathrm{i}, \mathrm{j})$ multiplied by the typology built area and the corresponding structural element unit weights.

Figure 34 shows, for each scenario and neighbourhood, the weight in tons of each debris type (W+B: wood and bricks, $\mathrm{C}+\mathrm{S}$ : concrete and steel). The total expected debris in the event of an earthquake of 
intensities 6, 7 and 7.5 are, respectively, 20800 tons (W+B:15030, C+S: 5769), 84275 tones (W+B:49823, $\mathrm{C}+\mathrm{S}: 34453)$ and 162811 tones $(\mathrm{W}+\mathrm{B}: 83795, \mathrm{C}+\mathrm{S}: 79016)$.

For intensity $6,72 \%$ of the expected debris will be wood and brick, but this percentage will decrease to $51 \%$ for intensity 7.5 , because of the biggest number of concrete buildings which will be damaged in this scenario.

Results show that the calculated volumes for the three scenarios are relevant and should be taken into account when designing the evacuation plan.

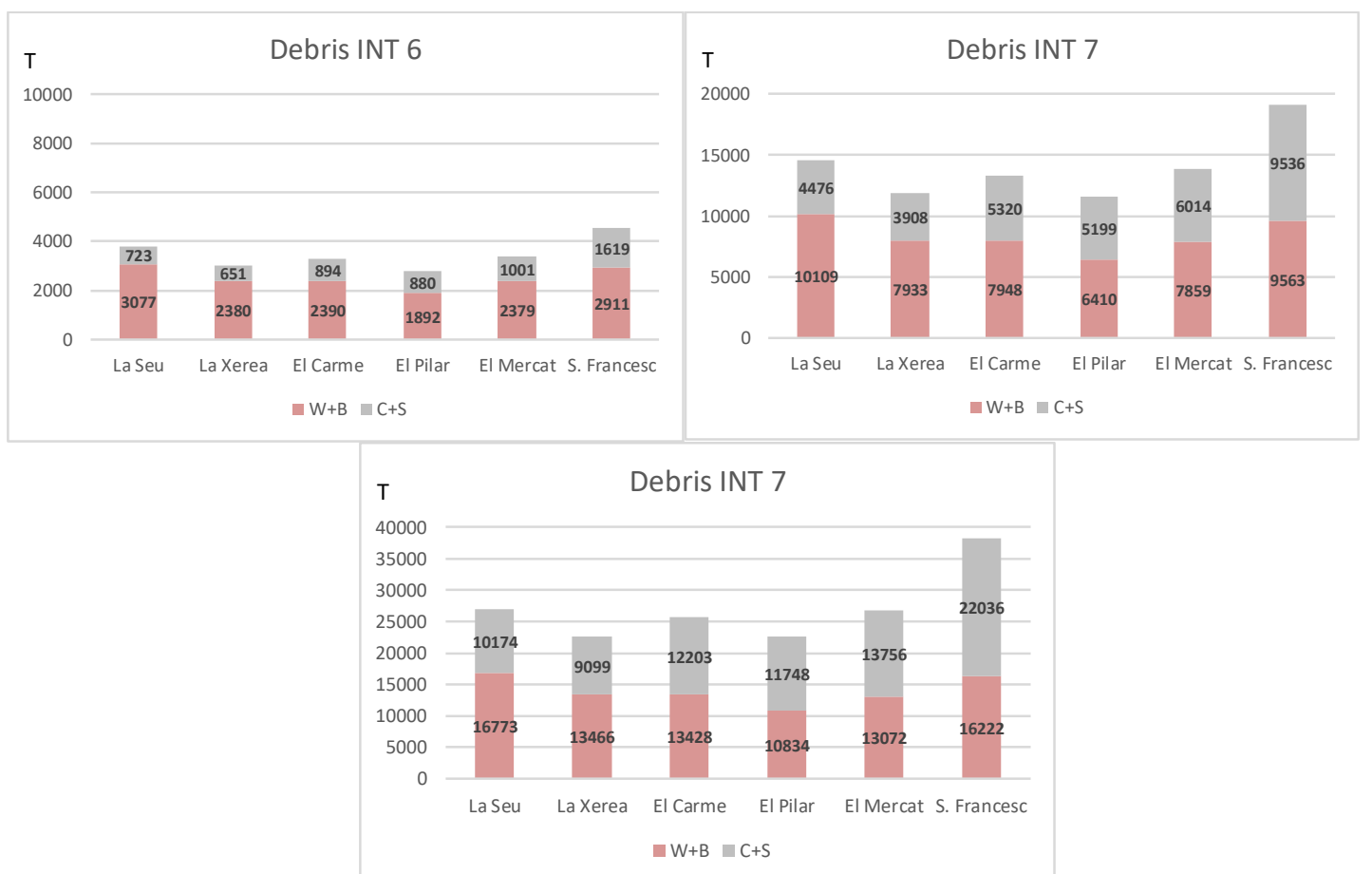

Fig. 34 Debris generated (in tons) in each neighbourhood and seismic scenario $(\mathrm{W}+\mathrm{B}$ : wood and bricks, $\mathrm{C}+\mathrm{S}$ : concrete and steel)

\section{CONCLUSIONS}

In this study, the seismic vulnerability of the residential buildings in the Ciutat Vella District, the old city centre of Valencia, has been assessed with the Vulnerability Index Method level 1, developed within the Risk-UE Project, estimating the seismic risk and determining the expected social and economic losses for seismic scenarios of intensities 6, 7 and 7.5.

The quality and reliability of the database developed by the authors, integrated within a GIS environment, has enabled to characterize each building, identifying the most vulnerable and analysing the specific elements which influence their vulnerability. The majority of these buildings correspond to unreinforced masonry typologies built before 1940, being part of the architectural heritage of the city.

The spatial distribution of the vulnerability and of the expected damage to the built environment for each earthquake scenario have been mapped by means of a Geographic Information System (GIS).

Despite being Valencia located in a low-to-moderate seismicity region, the obtained results show that the vulnerability of the building stock in Ciutat Vella is high and the seismic risk is significant, foreseeing a not negligible number of human losses and damaged buildings in case of probable future earthquakes.

An earthquake of 7.5 intensity during night time would cause 76 deaths being the expected homeless about 2262 people, $2.79 \%$ and $83 \%$ of the population in Ciutat Vella, respectively. Obviously, in the case of an event of intensity 6 these numbers are lower ( 1 death, $2.79 \%$ ond 156 homeless, $5 \%$ o, ), albeit not unimportant as to be worth considering.

Moreover, for a seismic scenario of intensity 7.5, 8\% of the total built residential area of Ciutat Vella will be destroyed $\left(209190 \mathrm{~m}^{2}\right)$, from which $68 \%$ correspond to residential buildings $\left(142500 \mathrm{~m}^{2}\right)$ included in the Catalogue of Listed buildings of the Special Protection Plan of Ciutat Vella (Ayuntamiento de Valencia, 2018), mainly belonging to the period 1800-1940 and being unreinforced masonry buildings 
(M3.1 typology). For seismic scenarios of intensities 6 and 7 the destroyed equivalent area corresponding to listed buildings will be $18400 \mathrm{~m}^{2}$ and $75250 \mathrm{~m}^{2}$ respectively.

It is worth noting too that the volume of expected debris is relevant, ranging from 162811 tons for an earthquake of intensity 7.5 to 20800 tons for an earthquake of intensity 6 . Considering the irregular urban layout of narrow streets, especially in El Carme, El Pilar and El Mercat neighbourhoods, the mobility should be also taken into account in the evacuation plan of Ciutat Vella.

In terms of economic costs, the predicted (estimated) values vary between 158 million euros for an earthquake of intensity 7.5 and 20 million euros for an earthquake of intensity 6 . Notwithstanding these high economic losses, it must be stressed that the heritage loss is invaluable and irreplaceable, being the building stock in Ciutat Vella a relevant patrimonial and cultural legacy.

It is therefore imperative, in view of the results of this study, to establish criteria for intervention not only in protected buildings, to safeguard the heritage, but also in all the buildings which are not seismically safe, avoiding as far as possible, their ruin in case of an earthquake and minimising human and economic losses. Likewise, the vulnerability of buildings included in refurbishment, renovation and repair processes or in rehabilitation plans, should be assessed, especially those protected, by applying more advanced and accurate methods.

\section{ACKNOWLEDGEMENTS}

The Authors wish to acknowledge the students Ana Pérez Recatalá, Beatriz Alborch Vidal and Blanca Salavert Pamblanco for their help in the building information retrieval under a collaboration grant program funded by the Ministry of Education, Culture and Sports. Finally, the authors what to thank P. McGowan for the review of the English version of the paper.

\section{REFERENCES}

Athmani A.E., Gouasmia A., Ferreira T. M., Vicente R., Khemis A. (2015). Seismic vulnerability assessment of historical masonry buildings located in Annaba city (Algeria) using non ad-hoc data survey. Bull Earthquake Eng 13:2283-2307. DOI 10.1007/s10518-014-9717-7

Ayuntamiento de Valencia 2017. Oficina de Estadística.

http://www.valencia.es/ayuntamiento/estadistica.nsf/ [Accessed 12 september 2018]

Ayuntamiento de Valencia, 2018. Plan Especial de protección de Ciutat Vella (PEP Ciutat Vella). http://www.valencia.es/ayuntamiento/urbanismo2.nsf/ [Accessed 5 December 2018

Barbat A.H., Carreño M.L., Pujades L.G., Lantada N., Cardona O.D., Marulanda M.C. (2010). Seismic vulnerability and risk evaluation methods for urban areas. A review with application to a pilot area. Structure and Infrastructure Engineering, Taylor and Francis Group vol 6: 17-38

Barbat, A.H, Pujades L. G, Lantada N. (2008). Seismic damage evaluation in urban areas using a capacityspectrum based method: Application to Barcelona. Soil Dynamics and Earthquake Engineering 28(10-11): $851-865$

Barbat, A.H., Yépez Moya, F., Canas, J.A. (1996). Damage Scenarios Simulation for Seismic Risk Assessment in Urban Zones. Earthquake Spectra 12(3):371-394.

Basset-Salom L., Guardiola-Víllora A., (2013). Influence of the maintenance in seismic response of Lorca historic centre masonry residential buildings after 11 May Earthquake. Studies, Repairs and Maintenance of Heritage Architecture XIII. WIT Transactions on the Built Environment 131:343-354.

Basset-Salom L., Guardiola-Víllora A., (2014) Seismic performance of masonry residential buildings in Lorca's city centre, after the $11^{\text {th }}$ May 2011 earthquake. Bull Earthquake Eng 12:2027-2048. DOI $10.1007 / \mathrm{s} 10518-013-9559-8$

Benedetti D., Petrini, V. (1984). Sulla Vulnerabilità di Edifici in Muratura: Proposta di un Metodo di Valutazione, L'industria delle Costruzioni, 149(1):66-74. 
Benedetti D., Benzoni G., Parisi, M. A. (1988), Seismic vulnerability and risk evaluation for old urban nuclei. Earthquake Engineering \& Structural Dynamics 16:183-201. doi: 10.1002/eqe.4290160203

Bernardini A., Gori R, Modena C. (1990). An application of coupled analytical models and experiential knowledge for seismic vulnerability analyses of masonry buildings. In A. Koridze (ed) Engineering Aspects of Earthquake Phenomena, Vol. 3:161-180. Oxon: Omega Scientific

Calvi G.M., Pinho R., Magenes G., Bommer J.J., Restrepo-Vélez L.F., Crowley H. (2006). Development of seismic vulnerability assessment methodologies over the past 30 years. ISET Journal of Earthquake Technology, 43(3):75-104

Catastro. Base de datos del catastro. https://www1.sedecatastro.gob.es [Accessed 15/09/2017-27/12/2018]

Chever L. (2012). Use of seismic assessment methods for planning vulnerability reduction of existing building stock. 15 ${ }^{\text {th }}$ World Conference on Earthquake Engineering, Lisbon, Portugal, September 24-28, 2012. http://www.mediterranee.cerema.fr/IMG/pdf/2012_seismic_vulnerability_assessment.pdf

Coburn A., Spence R. (2002). Earthquake Protection, 2nd ed., John Wiley and Sons Ltd., Chichester, England, ISBN 0-470-84923-1

D’Ayala D (2013) Assessing the seismic vulnerability of masonry buildings. In: Tesfamariam S, Goda K (eds) Handbook of seismic risk analysis and management of civil infrastructure systems. Woodhead Publishing, Sawston, pp 334-365. doi:10.1533/9780857098986.3.334

D’Ayala, D., Speranza, E. (2002). An Integrated Procedure for the Assessment of Seismic Vulnerability of Historic Buildings, Proceedings of the 12th European Conference on Earthquake Engineering, London, U.K., Paper No. 561

Dolce, M., Masi, A., Marino, M. and Vona, M. (2003). Earthquake Damage Scenarios of the Building Stock of Potenza (Southern Italy) Including Site Effects”, Bulletin of Earthquake Engineering, Vol. 1, No. 1, pp. 115-140.

FEMA-NIBS, Federal Emergency Management Agency National Institute of Building Sciences, (2000) HAZUS-1999 Earthquake loss estimation methodology technical manual, Washington, D.C., USA

FEMA-NIBS, Federal Emergency Management Agency, National Institute of Building Sciences, (2003). HAZUS-MH MR3·Technical Manual Multi-Hazard Loss Estimation Methodology. Earthquake model., Washington, D.C., USA

Feriche M. (2012). Elaboración de escenarios de daños sísmicos en la ciudad de Granada. Ph.D. tesis. Instituto andaluz de Geofísica y prevención de Desastres sísmicos. Universidad de Granada. http://digibug.ugr.es/handle/10481/29803\#.WZy_LbZLe70

Feriche M., Vidal F., Alguacil G., Navarro M., Aranda C. (2012). Vulnerabilidad y daño en el terremoto de Lorca de 2011, 7 a Asamblea Hispanoportuguesa de Geodesia y Geofísica, San Sebastián, España, 25-28 junio 2012

Feriche M., Vidal F., García R., Navarro M, Vidal M. D., Montilla, P., Piñero L (2009). Earthquake Damage Scenarios in Vélez- Málaga urban area (Southern Spain) applicable to Local Emergency Planning. 8th International Workshop on Seismic Microzoning and Risk Reduction, Almería, Spain, 15-18 March 2009.

Ferreira T.M., Maio R., Vicente R. (2017). Seismic vulnerability assessment of the old city centre of Horta, Azores: calibration and application of a seismic vulnerability index method. Bull Earthquake Eng (2017) 15:2879-2899 DOI 10.1007/s10518-016-0071-9

Franklin R., Caselles J.O., Canas J.A., Clapes J., Pujades Ll.G., Navarro MK (2006). Estimación de la respuesta del sitio mediante el método del cociente espectral aplicado a ruido ambiental. Aplicación a la Ciutat Vella de Valencia, Revista Internacional de Métodos Numéricos para Cálculo y Diseño en Ingeniería 22(2):169-191, http://hdl.handle.net/2099/4746 [Accessed 5 December 2012].

Giner J.J., Molina S., Jáuregui P. J. (2003). Sismicidad en la Comunidad Valenciana, Física de la Tierra 15:163-187. http://revistas.ucm.es/index.php/FITE/article/view/12668[Accessed 27/04/2018]. 
Giovinazzi S (2005). The vulnerability assessment and the damage scenario in seismic risk analysis. Ph.D Thesis, Technical University Carolo-Wilhelmina, Braunschweig, Germany and University of Florence, Italy

Giovinazzi S, Lagomarsino S (2002) WP04: Guidelines for the implementation of the 1 level methodology for the vulnerability assessment of current buildings: RISK-UE project. University of Genoa (Italy)

Giovinazzi, S., Lagomarsino, S. (2004). A Macroseismic Method for the Vulnerability Assessment of Buildings, Proceedings of the $13^{\text {th }}$ World Conference on Earthquake Engineering, Vancouver, Canada, 1-6 August, 2004, Paper No. 896.

Guardiola-Víllora A, Basset-Salom L, (2015). Escenarios de riesgo sísmico del distrito del Eixample de la ciudad de Valencia. Revista Internacional de Métodos Numéricos para el Cálculo y Diseño en Ingeniería 31(2):81-90. http://dx.doi.org/10.1016/j.rimni.2014.01.002

Guéguen Ph, Michel C., LeCorre L. (2007). A simplified approach for vulnerability assessment in moderate-to-low seismic hazard regions: application to Grenoble (France). Bull Earthquake Eng 5:467490 DOI 10.1007/s10518-007-9036-3

Grünthal G (1998). European Macroseismic Scale 1998. In: Cahiers du Centre Européen de Géodynamique et de Séismologie, 15, Luxembourg, 99p

gvSIG association (2009). gvSIG Desktop, the Open Source Geographic Information System. http://www.gvsig.com/en/home

Irizarry J., Lantada N., Pujades L.G., Barbat A.H., Goula X., Susagna T., Roca A. (2011). Ground-shaking scenarios and urban risk evaluation of Barcelona using the Risk-UE capacity spectrum based method. Bull Earthquake Eng 9(2):441-466. http://dx.doi.org/10.1007/s10518-010-9222-6.

Irizarry J., Macau A., Figueras S., Goula X., Lantada N., Vendrell S., Pujades L.G., Blázquez A. (2012) Seismic risk assessment for the city of Girona, Spain. $15^{\text {th }}$ World Conference on Earthquake Engineering, Lisbon, Portugal, September 24-28, 2012.

IVE, Instituto Valenciano de la Edificación (2018). Coste unitario de ejecución de edificación residencial. http://www.five.es/productos/herramientas-on-line/modulo-de-edificacion/ [Accessed October 2018]

Kappos A. J., Panagopoulos G., Panagiotopoulos C., Penelis G. (2006). A hybrid method for the vulnerability assessment of R/C and URM buildings. Bull Earthquake Eng 4:391-413. DOI $10.1007 / \mathrm{s} 10518-006-9023-0$

Kappos A.J., Stylianidis K.C., Pitilakis K. (1998). Development of seismic risk scenarios based on an hybrid method of vulnerability assessment. Natural Hazards 17(2):177-192

Lagomarsino S, Giovinazzi S (2006) Macroseismic and mechanical models for the vulnerability and damage assessment of current buildings. Bull Earthq Eng 4(4):415-443. doi:10.1007/s10518-006-9024-z

Lamego P., Lourenço P.B., Sousa M.L., Rui Marques R. (2017). Seismic vulnerability and risk analysis of the old building stock at urban scale: application to a neighbourhood in Lisbon. Bull Earthquake Eng 15:2901-2937 DOI 10.1007/s10518-016-0072-8

Lantada N. (2007). Evaluación del riesgo sísmico mediante métodos avanzados y técnicas GIS. Aplicación a la ciudad de Barcelona. PhD Thesis. U.P. Cataluña, Barcelona. http://hdl.handle.net/10803/6259 [Accessed January 2013].

Lantada N., Irizarry J., Barbat A., Goula X., Roca A., Susagna T., Pujades L.G. (2010). Seismic hazard and risk scenarios for Barcelona, Spain, using the Risk-UE vulnerability index method. Bull. Earthquahe Enginnering 8(2):201-229, http://dx.doi.org/10.1007/s10518-009-9148-z.

Lantada N., Pujades L.G., Barbat A.H. (2018). Earthquake Risk Scenarios in Urban Areas: A Review with Applications to the Ciutat Vella District in Barcelona, Spain. International Journal of Architectural Heritage, 12(7-8): 1112-1130, DOI: 10.1080/15583058.2018.1503367 
Llopis A., Perdigón L., Taberner F., 2004. Cartografía Histórica de la ciudad de Valencia, volumen 1, (1608-1929). Facsimil editions Digitals.

Maio R., Ferreira T.M., Vicente R., and Estêvão J. (2016). Seismic vulnerability assessment of historical urban centres: case study of the old city centre of Faro, Portugal. Journal of Risk Research, 19(5):551580, DOI: 10.1080/13669877.2014.988285

Martínez-Cuevas S., Benito M.B., Cervera J., Morillo M.C, Luna, M. (2017). Urban modifiers of seismic vulnerability aimed at Urban Zoning Regulations. Bull Earthquake Eng 15:4719-4750 DOI $10.1007 / \mathrm{s} 10518-017-0162-2$

Martínez-Cuevas S., Gaspar-Escribano J. M. (2016) Reassessment of intensity estimates from vulnerability and damage distributions: the 2011 Lorca earthquake. Bull Earthquake Eng 14:2679-2703

Mileto C., Vegas F. 2005. Centro histórico de Valencia. Ocho siglos de arquitectura residencial. ISBN: 978-84-943475-5-9. Ed. General de ediciones de Arquitectura, S.L.

Milutinovic ZV, Trendafiloski GS (2003) WP04. Vulnerability of current buildings. RISK-UE project: an advanced approach to earthquake risk scenarios with applications to different European towns. Institute of Earthquake Engineering and Engineering Seismology (IZIIS), Skopje.

Mouroux, P., Bertrand, E., Bour, M, Le Brun, B., Depinois, S., Masure Ph. (2004). The European RISKUE Project: An advanced approach to earthquake risk scenarios, in: Proc. of the 13th World Conference on Earthquake Engineering (13 WCEE), Vancouver, BC, Canada, 1-6 August, paper 3329.

Müge ün E. (2011). An integrated seismic loss estimation methodology: a case study in north-western Turkey. PhD Thesis. School of Natural and Applied Sciences, Middle East Technical University, Turkey

Novelli V.I. (2017) Hybrid method for the seismic vulnerability assessment of historic masonry city centres. Ph.D. Thesis. University College London.

http://discovery.ucl.ac.uk/1553222/1/Novelli_ID_PHD_thesis.pdf

Ortiz Herrada M., 2002 "El-centro-historico-de-valencia-un-modelo-de-intervencion-patrimonial”. Actas del I Congreso del GEIIC. Conservación del Patrimonio: evolución y nuevas perspectivas.

https://www.ge-iic.com/2006/06/30/actas-del-i-congreso-del-geiic-conservacion-del-patrimonioevolucion-y-nuevas-perspectivas/ [Accessed 27 April 2018].

Roca A., Irizarry J., Lantada N., Barbat A., Goula X., Pujades L.I., Susagna T. (2006). Método Avanzado para la Evaluación de la Vulnerabilidad y el Riesgo Sísmico. Aplicación a la Ciudad de Barcelona. Física de la Tierra 18:183-203.

Ródenas J. L., Tomás A, García-Ayllón S. (2018) Advances in seismic vulnerability assessment of reinforced concrete buildings applied to the experience of Lorca (Spain) 2011 earthquake. Int. J. Comp. Meth. and Exp. Meas. 6(5):887-898 DOI: 10.2495/CMEM-V6-N5-887-898.

Ros A., Casar J.I., Romero B., Gomez A., Soler P., Alcalde C., Pecourt J., Matamoros C., Esparza R., 1999. 5 años de intervenciones en Ciutat Vella: 1992-1997. ISBN: 9788486828240. Ed. CTAV, Valencia. http://www.arquitectosdevalencia.es/publicaciones/ctav/5-anos-de-intervenciones-en-ciutat-vellavalencia-1992-1997

Sousa ML., Campos Costa A. (2016). Evolution of earthquake losses in Portuguese residential building stock. Bull Earthquake Eng 14:2009-2029. DOI 10.1007/s10518-015-9809-z

Tomás A, Ródenas J. L., García-Ayllón S. (2017). Proposal for new values of behaviour modifiers for seismic vulnerability evaluation of reinforced concrete buildings applied to Lorca (Spain) using damage data from the 2011 earthquake. Bull Earthquake Eng 15:3943-3962 DOI 10.1007/s10518-017-0100-3

Tyagunov S., Stempniewski L., Grünthal G., Wahlström R., Zschau J. (2004). Vulnerability and risk assessment for earthquake prone cities. $13^{\text {th }}$ World Conference on Earthquake Engineering, Vancouver, B.C., Canada, August 1-6, 2004, Paper No. 868. 
URSUA. Unidad de Registro Sísmico Universidad de Alicante (2010). Mapas de Intensidad sísmica esperada en la Comunidad Valenciana incluyendo efecto del sitio para 500 años y 1000 años. http://web.ua.es/ursua [Accessed 5 October 2017].

Vacareanu R., Lungu D., Aldea A., Arion C. (2004). WP07. Report Seismic Risk Scenarios Handbook, Risk-UE Project, Bucarest

Vicente R., Parodi S., Lagomarsino S., $\cdot$ Varum H., Mendes Silva J. A. R. (2011). Seismic vulnerability and risk assessment: case study of the historic city centre of Coimbra, Portugal. Bull Earthquake Eng 9(4):10671096. DOI 10.1007/s10518-010-9233-3

Whitman R.V., Reed J.W. Hong, S.T. (1973). Earthquake Damage Probability Matrices. Proceedings of the $5^{\text {th }}$ World Conference on Earthquake Engineering, Rome, Italy, 2: 2531-2540 